\title{
REVIEW ARTICLE Advances in the development of imaging probes and aggregation inhibitors for alpha-synuclein
}

\author{
Ming-ming $\mathrm{Xu}^{1}$, Philip Ryan ${ }^{2,3,4}$, Santosh Rudrawar ${ }^{2,3,4}$, Ronald J Quinn ${ }^{1}$, Hai-yan Zhang ${ }^{5}$ and George D Mellick ${ }^{1}$
}

\begin{abstract}
Abnormal protein aggregation has been linked to many neurodegenerative diseases, including Parkinson's disease (PD). The main pathological hallmark of PD is the formation of Lewy bodies (LBs) and Lewy neurites, both of which contain the presynaptic protein alpha-synuclein (a-syn). Under normal conditions, native a-syn exists in a soluble unfolded state but undergoes misfolding and aggregation into toxic aggregates under pathological conditions. Toxic a-syn species, especially oligomers, can cause oxidative stress, membrane penetration, synaptic and mitochondrial dysfunction, as well as other damage, leading to neuronal death and eventually neurodegeneration. Early diagnosis and treatments targeting PD pathogenesis are urgently needed. Given its critical role in PD, a-syn is an attractive target for the development of both diagnostic tools and effective therapeutics. This review summarizes the progress toward discovering imaging probes and aggregation inhibitors for a-syn. Relevant strategies and techniques in the discovery of a-syn-targeted drugs are also discussed.
\end{abstract}

Keywords: Parkinson's disease; alpha-synuclein; imaging probes; aggregation inhibitors; thioflavin-T; mass spectrometry

Acta Pharmacologica Sinica (2020) 41:483-498; https://doi.org/10.1038/s41401-019-0304-y

\section{INTRODUCTION}

Parkinson's disease (PD) is a progressive neurodegenerative disorder that causes severe motor deficits. Common symptoms include rigidity, bradykinesia, tremor and postural instability [1]. With disease progression, nonmotor symptoms, such as depression, psychosis, falls, and sleep disturbance, also emerge [2]. Globally, $1.5 \%$ of the population over 65 years of age [3] and more than 5 million people [4] are affected by this devastating disease. $P D$ is pathologically characterized by the substantial loss of dopamine (DA)-containing neurons in the midbrain [5] and the presence of intraneuronal cytoplasmic inclusions [6], known as Lewy bodies and Lewy neurites [7], both of which comprise alphasynuclein (a-syn) aggregates.

A definitive diagnosis of PD has to rely on histopathological postmortem analysis and requires the detection of dopaminergic cell loss and the presence of Lewy bodies and Lewy neurites. For living patients, several clinical diagnostic criteria have been formulated, including the UK Parkinson's Disease Society Brain Bank (UKPDSBB) [8], the National Institute of Neurological Disorders and Stroke (NINDS) criteria [9] and the Movement Disorder Society Clinical Diagnostic Criteria for PD [10]. However, the diagnostic accuracy obtained by using these criteria is only between $75 \%$ and $85 \%[11,12]$. Compared with the observation of clinical symptoms, neuroimaging may help to increase diagnostic precision. Clinically available imaging approaches include positron emission tomography (PET), single-photon emission computed tomography (SPECT) and magnetic resonance imaging (MRI). PET and SPECT use a variety of radiotracers to quantitatively measure the metabolic and neurochemical changes in the brains. For example, fluorine-18-L-dihydroxyphenylalanine $\left({ }^{18} \mathrm{~F}\right.$-Dopa) PET can mark dopaminergic deficiencies in the brains of patients with PD [13]. MRI uses different sequences and contrasts to study brain structure and function [14]. Although substantial progress has been made in PD neuroimaging, currently, it can only be used as a supplementary tool to clinical examination [15].

Increasing evidence suggests that prior to the motor phase of classical PD there is a prodromal period that lasts for several years [16]. After the appearance of typical motor features, the disease can continue to progress for many years or even decades, although it is impossible to predict the trajectory of this progression at diagnosis [17]. The pathological changes in the central nervous system during the prodromal phase, such as the formation of a-syn aggregates, appear to mirror the occurrence of motor and nonmotor symptoms. A timeline of PD from onset to death has been proposed [17], which not only promotes a comprehensive understanding of the overall disease process but is also a reminder that before a patient shows any PD-related clinical symptoms, the disease may have progressed severely and possibly irreversibly as a result of neuronal dysfunction and cell loss [18, 19].

In the future, the traditional symptom-based clinical examination may be pre-empted by the use of biomarkers that may assist in identifying early disease-specific changes by early prodromal diagnosis, namely detecting specific changes in biomarkers during the early development of PD [20]. Since diagnosis informs treatment, novel therapeutics targeting the potential pathological culprits need to be developed.

\footnotetext{
${ }^{1}$ Griffith Institute for Drug Discovery, Griffith University, Brisbane Innovation Park, Don Young Road, Nathan, QLD 4111, Australia; ${ }^{2}$ School of Pharmacy and Pharmacology, Griffith University, Gold Coast, QLD 4222, Australia; ${ }^{3}$ Menzies Health Institute Queensland, Griffith University, Gold Coast, QLD 4222, Australia; ${ }^{4}$ Quality Use of Medicines Network, Griffith

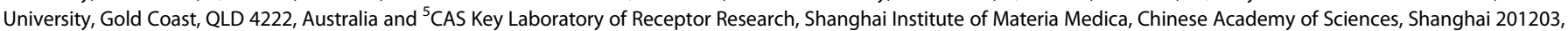
China

Correspondence: Ming-ming Xu (manny.xu@griffithuni.edu.au) or George D Mellick (g.mellick@griffith.edu.au)
}

Received: 26 May 2019 Accepted: 29 August 2019

Published online: 4 October 2019 
Until now, no neuroprotective or neurorestorative therapy has been found for the treatment of PD. Existing treatments predominantly target dopamine-related symptoms. Few, if any, target nondopaminergic symptoms, which cause a severe burden for patients in the advanced stages of the disease. In addition, current PD treatments provide little or no relief for disease progression because they do not alter the rate or extent of neuronal cell loss [21, 22]. Therefore, for the future direction of PD medications, the priority is the development of neuroprotective or neurorestorative drugs that can stop or at least relieve disease progression and the relevant nonmotor symptoms [23]. To realize this goal, it is necessary to identify and target the key culprit underlying the pathogenesis of PD.

\section{ALPHA-SYNUCLEIN AND ITS FUNCTIONAL ROLE}

Native a-syn is a small protein encoded by the gene SNCA, with a molecular mass of $14.5 \mathrm{kDa}$ (140 amino acids) [24]. Its primary structure (Fig. 1) shows three different regions: the $\mathrm{N}$-terminal region (residues $1-60$ ) that is characterized by repetitions of a highly conserved lysine-rich motif KTK(E/Q)GV, the hydrophobic central part (residues 61-95, known as the non-amyloidogenic component (NAC) region), and the acidic C-terminal region (residues 96-140). The amphipathic $N$-terminal region has a structural alpha-helix propensity similar to apolipoprotein-binding domains, suggesting that a-syn is a membrane-bound protein [25]. The NAC region is believed to be involved in protein aggregation by mediating the conformational changes of a-syn from random coil to a beta-sheet structure [24]. The C-terminal region, having no distinct secondary structure, has been reported to interact with the $\mathrm{N}$-terminal region or the NAC region to maintain the natively unfolded state of a-syn [26]. Although it is widely believed that a-syn exists mainly as monomer, studies have also shown that endogenous a-syn can form tetramers [27, 28], which comprise an alpha-helical secondary structure and show little tendency to form aggregates [29]. All these findings suggest that there may be a dynamic equilibrium between different $a$-syn conformational states [30].

The exact normal functions of a-syn are not well understood. Although some animal studies suggest that an a-syn-knockout is not fatal, deficiencies in synaptic transmissions were observed in some knockout animal lines [31, 32]. In neurons a-syn is mainly localized at the presynaptic terminals $[33,34]$ and is associated with the reserve pool of synaptic vesicles [35-37]. a-Syn can promote the assembly of the presynaptic soluble $\mathrm{N}$-ethylmaleimide-sensitive factor activating protein receptor (SNARE) protein complex, that mediates vesicle fusion, which is a vital step for the release of neurotransmitters, including dopamine [38]. In addition to its role in synaptic transmission, a-syn is also involved in the suppression of apoptosis [39], antioxidation [40] and even regulation of dopamine biosynthesis [41, 42].

\section{ROLE OF ALPHA-SYNUCLEIN IN PD PATHOGENESIS}

The first connection between a-syn and PD was made in 1997 when point mutations in the SNCA gene were identified in familial PD cases [43]. To date, six missense mutations in SNCA are known to lead to autosomal dominant PD: A53T [43], A30P [44], E46K [45],

$$
\begin{aligned}
& 1 \text { MDVFMKGLSKAKEGVVAAAEKTKQGVAEAA } \\
& 31 \text { GKTKEGVLYVGSKTKEGVVHGVATVAEKTK } \\
& 61 \text { EQVTNVGGAVVTGVTAVAQKTVEGAGSIAA } \\
& 91 \text { ATGFVKKDQLGKNEEGAPQEGILEDMPVDP } \\
& 121 \text { DNEAYEMPSEEGYQDYEPEA }
\end{aligned}
$$

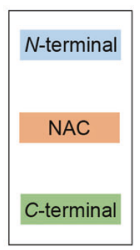

Fig. 1 The primary sequence and the three distinct regions of $\alpha$-syn
H50Q [46], G51D [47], and A53E [48]. Meanwhile, the link between a-syn and PD was further elucidated with the discovery of duplications and triplications of the SNCA gene in PD families, which also suggested that increased expression of a-syn was a causative factor of PD $[49,50]$. Moreover, certain polymorphisms in SNCA, such as the dinucleotide repeat REP1 located in the SNCA promoter (SNCA-REP1), a -770 and -116 base-pair (bp) singlenucleotide polymorphism, are major risk factors for sporadic PD, and are thought to result from altered expression of the gene product [51, 52]. Genome-wide association studies have also consistently revealed highly significant regions of genetic variation around the SNCA gene as contributors to the risk of PD. A meta-analysis of genome-wide association studies has identified 17 new PD risk loci [53].

As mentioned earlier, the NAC region of monomeric a-syn mediates the misfolding from a random coil to a beta-sheet structure, leading to the formation of oligomers, protofibrils and eventually mature fibrils [54]. This pathway is also shared by other amyloid-forming proteins such as beta-amyloid $(A \beta)$, tau and human islet amyloid polypeptide (hIAPP). The fluorescent dye thioflavin-T (ThT) is a widely used "gold standard" for staining and identifying fibrils of these amyloid proteins [55]. Kinetics studies of a-syn aggregation using ThT $[56,57]$ revealed a sigmoidal curve of fibril growth, which is composed of the lag phase representing the nucleation stage, an exponential phase representing the elongation stage and a plateau phase corresponding to the completion of fibril formation [58].

It is natural to deduce that a-syn can cause toxicity to neurons, as cell death is a major hallmark of PD and a-syn plays a causal role in the disease. Given that all known clinical mutations are thought to be linked to increased a-syn aggregation and that the main components of Lewy bodies and Lewy neurites are aggregated a-syn fibrils, it was initially believed that a-syn fibrils were the toxic species. Later, increasing evidence from both in vitro and in vivo studies has supported the proposal that oligomeric species are the most pathogenically relevant [59-63]. As a result, the oligomers may be a better therapeutic target, as the aggregated Lewy bodies themselves might be protective and represent a form of an aggresome $[64,65]$.

a-Syn oligomers are believed to exert toxicity both intracellularly and extracellularly. Within the cytoplasm, a-syn oligomers can inhibit the Hsp 70 chaperone system which is important for protein refolding [66]. a-Syn oligomers can also bind to and inhibit the activities of proteasomes [67], thus affecting protein degradation. Consequently, proteostasis is impaired, leading to endoplasmic reticulum (ER) stress and finally cell death. In vivo, a-syn oligomers have been detected within the ER lumen, and treatment with an inhibitor of ER stress, dramatically delayed the onset of motoric symptoms and decreased the accumulation of a-syn oligomers [68], suggesting that ER stress is involved in the toxicity of a-syn oligomers. In addition, a-syn plays an important role in the assembly of the presynaptic SNARE protein complex. The formation of oligomeric a-syn can inhibit SNARE-mediated vesicle docking and consequently reduce exocytosis, suggesting that inhibition of dopamine release is a potential mechanism in PD [63]. a-Syn oligomers can also induce the dysfunction of synapses by compromising the axonal transport of critical presynaptic proteins [69]. Other potential intracellular targets of a-syn oligomers include mitochondria [70], lysosomes [71] and microtubules [72].

Extracellular sources of a-syn oligomers can form pores in cell membranes, causing an increase in intracellular calcium levels that leads to cell death [59]. Exposure of neurons to exogenous a-syn oligomers can activate glutamatergic receptors, resulting in longterm potentiation (LTP) and excitotoxicity that leads to neuronal death $[73,74]$. Moreover, there is significant evidence that a-syn oligomers can transfer from neuron to neuron or to glial cells via a prion-like process $[75,76]$, which may explain the spread of Lewy pathology throughout the brain in PD [77]. 
Overall, the accumulation of a-syn aggregates is a major pathological hallmark of PD and a priority target for drug development given its hypothesized contribution to neurodegeneration. In vivo imaging of a-syn pathology could be useful as a biomarker of the presence of the disease, disease progression and as a pharmacodynamic tool for drug development. Therefore, asyn imaging is a critical need for PD research [78]. Moreover, since a-syn aggregation is regarded as a major pathogenic process in $P D$, several strategies exist for the prevention of a-syn toxicity [79]. Among them, inhibition of a-syn aggregation remains an extremely attractive target for drug development [30]. The representative progress in the development of imaging probes and aggregation inhibitors over the past decade will be discussed further.

\section{ALPHA-SYNUCLEIN IMAGING PROBES}

Radiotracers

Although several PET/SPECT tracers targeting the dopamine system have been used clinically, as reviewed by Politis [15], Braak staging of the PD brain suggests that the severe loss of dopaminergic neurons occurs at stage 4, while Lewy body pathology appears as early as stage 1 . As such, imaging a-syn pathology, rather than dopaminergic changes, would be more suitable for early diagnosis in the prodromal period of PD. While great progress has been made toward developing imaging probes for other amyloid-forming proteins [80] (and notably three $A \beta$ imaging probes have gained FDA approval), the development of a-syn imaging probes is still at an early stage. Despite the fact that there are no selective a-syn PET or SPECT probes for clinical PD diagnosis, several a-syn imaging probes have been developed and tested over the past decade (Fig. 2, Table 1).

Amyloid proteins, such as $A \beta$ and $\alpha-s y n$, tend to form similar beta-sheet structures upon aggregation. As a result, probes that can interact with $A \beta$ aggregates also have the potential to bind to aggregated $\alpha$-syn. Following this rationale, some established $A \beta$ PET probes have been evaluated against a-syn. One well-known example is ${ }^{11} \mathrm{C}$-Pittsburgh compound-B (PIB, 1), a derivative of thioflavin-T (ThT) which is the gold standard for staining all types of amyloid proteins. Probe 1 exhibited a similar binding affinity $\left(K_{d}=\right.$ $4 \mathrm{nM}$ ) for in vitro generated a-syn fibrils compared to $A \beta$ [81], but failed to bind to brain homogenates containing Lewy bodies [82]. Additionally, probe $\mathbf{1}$ displayed poor selectivity for a-syn in the staining of brain sections where $A \beta$ was also present [82].

Benzoxazole BF227 is another established $A \beta$-binding probe. ${ }^{18} \mathrm{~F}-\mathrm{BF} 227$ (2) was proven to bind to a-syn fibrils at an equimolar concentration compared to $A \beta_{1-42}$ fibrils, but the binding affinity for a-syn fibrils $\left(K_{\mathrm{d}}=9.63 \mathrm{nM}\right)$ was approximately sevenfold lower [83]. However, like ${ }^{11} \mathrm{C}-\mathrm{PIB}$, probe $\mathbf{2}$ also failed to bind to brain homogenates containing Lewy bodies [83]. A follow-up in vivo study using an accelerated mouse model of synucleinopathy failed to observe a significant difference in the brains of a-syn transgenic mice compared with a-syn-KO mice after treatment with probe 2 [84]. These results suggest that it is necessary to develop specific a-syn PET probes.

To discover selective ligands for a-syn aggregates, $\mathrm{Yu}$ et al. synthesized a series of phenothiazine derivatives and evaluated their binding affinities for a-syn fibrils with a ThT competition assay. Compounds $11 \mathrm{~b}, 16 \mathrm{a}$ and $16 \mathrm{~b}$ exhibited $K_{\mathrm{i}}$ values of less than $60 \mathrm{nM}$ (32.10 nM for $11 \mathrm{~b}, 48.96 \mathrm{nM}$ for $16 a$ and $57.94 \mathrm{nM}$ for $16 \mathrm{~b})$ and were considered for further study [85]. Later, ${ }^{125}$ I labeled $16 \mathrm{~b}(3)$, denoted ${ }^{125} \mathrm{I}-\mathrm{SIL} 23$, was synthesized and tested by the same research group. Probe 3 can bind to recombinant a-syn fibrils and brain homogenates from PD patients and a-syn transgenic mice. Probe $\mathbf{3}$ exhibited a relatively high binding affinity for $a$-syn fibrils compared with $A \beta_{1-42}$ fibrils (fivefold lower than a-syn) and tau fibrils (twofold lower than a-syn) but the selectivity was not high enough for in vivo imaging [86]. Using a

Table 1. Characteristics of representative radiotracers

\begin{tabular}{|c|c|c|c|c|c|}
\hline No. & $K_{\mathrm{d}} / K_{\mathrm{i}}$ & $\begin{array}{l}\text { Other } \\
\text { targets }\end{array}$ & Scaffold & Status & Ref. \\
\hline 1 & $K_{\mathrm{d}}=4 \mathrm{nM}^{\mathrm{a}}$ & $\mathrm{A} \beta$, tau & Benzothiazole & in vitro & {$[81,82]$} \\
\hline 2 & $K_{\mathrm{d}}=9.63 \mathrm{nM}^{\mathrm{a}}$ & $A \beta$ & Benzoxazole & in vivo & [83] \\
\hline 3 & $\begin{array}{l}K_{\mathrm{d}}=148 \mathrm{nM}^{\mathrm{a}} \\
K_{\mathrm{i}}=57.94 \mathrm{nM}^{\mathrm{b}, \mathrm{c}}\end{array}$ & $\mathrm{A} \beta$, tau & Phenothiazine & in vivo & {$[85,86]$} \\
\hline 4 & $K_{\mathrm{i}}=66.2 \mathrm{nM}^{\mathrm{c}, \mathrm{d}}$ & $\mathrm{A} \beta$, tau & Phenothiazine & in vivo & [87] \\
\hline 5 & $K_{\mathrm{i}}=19.9 \mathrm{nM}^{\mathrm{c}, \mathrm{d}}$ & $\mathrm{A} \beta$, tau & Phenothiazine & in vivo & [87] \\
\hline 6 & $\begin{array}{l}K_{\mathrm{d}}=8.9 \mathrm{nM}^{\mathrm{a}} \\
K_{\mathrm{i}}=2 \mathrm{nM}^{\mathrm{b}, \mathrm{c}}\end{array}$ & $\mathrm{A} \beta$, tau & $\begin{array}{l}\text { 3-(benzylidine) } \\
\text { indolin-2-one }\end{array}$ & in vitro & {$[88]$} \\
\hline 7 & $K_{\mathrm{d}}=5.4 \mathrm{nM}^{\mathrm{a}}$ & $A \beta$ & Chalcone & in vitro & [89] \\
\hline 8 & $K_{\mathrm{d}}=99.5 \mathrm{nM}^{\mathrm{a}, \mathrm{c}}$ & $A \beta$ & Benzoimidazole & in vitro & [90] \\
\hline \multicolumn{6}{|c|}{$\begin{array}{l}\text { a Determined by saturation binding assays } \\
\text { betermined by ThT competition assays } \\
{ }^{9} \text { Isotope unlabeled } \\
{ }^{d} \text { Determined by }{ }^{125} \text { I-SIL23 competition assays }\end{array}$} \\
\hline
\end{tabular}

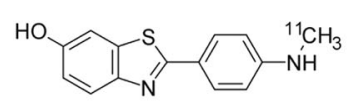

1<smiles>COc1ccc2c(c1)Sc1cc([N+](=O)[O-])ccc1N2</smiles>

4<smiles>CN(C)c1ccc(/C=C/C=C/C=C/C=C/C(=O)c2ccc([131I])cc2)cc1</smiles><smiles>CN(C)c1ncc(/C=C/c2nc3ccc(OCC[18F])cc3o2)s1</smiles>

2<smiles>O=[N+]([O-])c1ccc2c(c1)Sc1cc(OCC[18F])ccc1N2</smiles>

5<smiles>[13CH3]/C=C/COc1ccc2c(c1)Sc1cc([N+](=O)[O-])ccc1N2</smiles>

3<smiles>O=C1/C(=C\C=C\c2ccc([N+](=O)[O-])cc2)c2ccccc2N1Cc1ccc(OCC[18F])cc1</smiles>

Fig. 2 Radiotracers for $\alpha$-syn 
probe 3 -based competition binding assay, the binding affinities $\left(K_{\mathrm{i}}\right.$ values) of the aforementioned $11 \mathrm{~b}$ (renamed 2a) and $16 \mathrm{a}$ (renamed 2b) were calculated (66.2 nM for $2 \mathrm{a}, 19.9 \mathrm{nM}$ for $2 \mathrm{~b}$ ), further confirming the potency determined previously [87]. In addition, ${ }^{11} \mathrm{C}-2 \mathrm{a}(\mathbf{4})$ and ${ }^{18} \mathrm{~F}-2 \mathrm{~b}(\mathbf{5})$ were synthesized and proven to cross the blood-brain barrier (BBB) in Sprague-Dawley (SD) rats. Both radiotracers exhibited high initial uptake $(0.953 \% \mathrm{ID} / \mathrm{g}$ for $4,0.758 \% \mathrm{ID} / \mathrm{g}$ for $\mathbf{5}$ ), homogeneous distribution and rapid washout kinetics. The authors believed that these two radiotracers could be good leads for the discovery of selective imaging probes for a-syn [87].

Identifying new chemical scaffolds is necessary for developing specific radiotracers with high selectivity for a-syn fibrils versus other amyloid proteins such as $A \beta$ and tau. Recently, a series of compounds based on the 3-(benzylidene)-indolin-2-one scaffold were synthesized and the most potent compound was $46 \mathrm{a}$, having a high affinity $\left(K_{\mathrm{i}}=2 \mathrm{nM}\right)$ and very good selectivity for a-syn versus $\mathrm{A} \beta \quad\left(K_{\mathrm{i}}=142.4 \mathrm{nM}\right)$ and tau fibrils $\left(K_{\mathrm{i}}=80.1 \mathrm{nM}\right)$. The binding affinity of ${ }^{18} \mathrm{~F}$-labeled $46 \mathrm{a}(6)$ was determined from a saturation binding assay. The $K_{\mathrm{d}}$ of probe $\mathbf{6}$ for a-syn fibrils was $8.9 \mathrm{nM}$ while the values for $A \beta$ and tau fibrils were 271 and $50 \mathrm{nM}$, respectively. However, probe $\boldsymbol{6}$ is not believed to be a suitable PET tracer for in vivo imaging due to poor druggability [88].

Flavonoids are a common source for the discovery of inhibitors of $A \beta$ aggregation as well as $a-$-syn. Chalcone is a good example and Ono et al. synthesized a series of chalcone derivatives in the hope of discovering new scaffolds for a-syn imaging. Of all four synthesized compounds, IDP-4 showed the most selective binding to a-syn aggregates $\left(K_{d}=5.4 \mathrm{nM}, K_{d}=16.24 \mathrm{nM}\right.$ for $\left.A \beta\right)$. Fluorescent staining of PD brain sections confirmed the affinity of IDP-4 for Lewy bodies. Unfortunately, ${ }^{125}$ I-IDP-4 (7) displayed the lowest initial uptake of the four compounds synthesized $(0.45 \% \mathrm{ID} / \mathrm{g})$ in normal mice, making it difficult to use for in vivo imaging [89]. More recently, the same group also synthesized three novel radioiodinated benzoimidazole (BI) derivatives based on the previous findings: (1) the benzoimidazole scaffold could bind to a-syn aggregates; (2) the diene moiety helps to increase the affinity for a-syn aggregates; and (3) introduction of large substituents increases the selectivity for a-syn. Compound BI-2 showed the highest selectivity and binding affinity for a-syn aggregates $\left(K_{d}=99.5 \mathrm{nM}, K_{d}=727 \mathrm{nM}\right.$ for $\left.A \beta\right)$. Fluorescent staining of PD and AD brain sections using $\mathrm{BI}-2$ was conducted and $\mathrm{BI}-2$ clearly stained Lewy bodies but failed to label $A \beta$ aggregates, further confirming its selectivity for a-syn. However, the promising compound ${ }^{125} \mathrm{I}-\mathrm{BI}-2$ (8) exhibited low initial uptake $(0.56 \% \mathrm{ID} / \mathrm{g})$ and poor washout kinetics in normal mouse brains, suggesting that the introduction of bulky substitution groups may affect penetration into the BBB [90]. The authors also mentioned that criteria exist for ideal $A \beta$ and tau imaging probes according to previous reports [91, 92]: (1) an initial brain uptake up to $4 \% \mathrm{ID} / \mathrm{g}$ at 2-min postinjection in mice; and (2) a remaining amount of less than $1 \% \mathrm{ID} / \mathrm{g}$ at $30-\mathrm{min}$ postinjection in normal mouse brains. Clearly, none of the reported probes for a-syn met these criteria, including probe $\mathbf{8}$.

In the past decade, significant progress toward discovering useful a-syn radiotracers has been made; however, an ideal, druggable probe possessing high affinity and selectivity for a-syn has yet to be identified [93].

\section{Fluorescent probes}

Fluorescence imaging presents a promising alternative technique to radiotracers. In contrast to PET/SPECT techniques, fluorescence imaging is monitored in real time, is inexpensive, is nonradioactive and is of high-resolution when using near-infrared fluorescence (NIRF) imaging probes. As a technique, fluorescence imaging is progressively being explored for the neuroimaging of $A \beta$ aggregates [94]. The ideal fluorescent probe will not only possess high selectivity and binding affinity, penetrate rapidly into the BBB and be cleared quickly from normal brain regions, but will also have low background fluorescence (ideal emission wavelength of greater than $650 \mathrm{~nm}$ ) in addition to producing a significant increase in fluorescence upon binding to target proteins. Given that aggregated $\alpha$-syn is far less abundant in the brain than $A \beta, \alpha-$ syn fluorescent probes will require very high selectivity for a-syn over $A \beta$ and tau. Since the majority of $\alpha$-syn is found intracellularly, in addition to penetrating the BBB, such a probe has to cross the cell membrane [78].

ThT is a widely used fluorescent dye for the nonselective staining of protein aggregates. Its in vivo utility is limited due to its positive charge which affects its penetration through the BBB and its emission wavelength is not suitable for in vivo imaging. To search for improved fluorescent probes for a-syn, Celej et al. evaluated the abilities of several $N$-arylaminonaphthalene sulfonate (NAS) derivatives to be used as fluorescent markers for a-syn aggregates since the NAS scaffold has a long history of being applied to study the molecular microenvironment and conformation of proteins. Compounds 2,6-ANS (Fig. 3, 9), 2,6-TNS (10), bisANS (11), and bis-TNS (12) exhibited slightly improved binding affinity ( $K_{d}$ values: $8.8,11.7,8.6$ and $11.6 \mu \mathrm{M}$, respectively) for asyn fibrils compared with ThT $\left(K_{d}=14.9 \mu \mathrm{M}\right)$ [95]. Although these molecules also displayed advantages over ThT in terms of providing structural information during a-syn fibrillation, they are still not useful as imaging probes as a result of their charged properties and unideal emission wavelengths.

In an endeavor to search for novel specific fluorescent probes for a-syn, Volkova and coworkers studied the potential of a series of monomethine and trimethinecyanines to detect the formation of a-syn fibrils. The most potent dyes, T-284 (13) and SH-516 (14), had similar binding affinities to ThT but showed large increases in fluorescence ( 9.5-fold for 13 and $~ 7.6$-fold for 14) upon binding to a-syn fibrils relative to ThT (2.9-fold). A notable improvement was that the emission wavelengths of probes 13 and 14 after binding to a-syn fibrils were determined to be 570 and $580 \mathrm{~nm}$, respectively, compared with ThT $(478 \mathrm{~nm})$ [96]. The specificity of these two dyes was not evaluated by assays against other amyloid proteins.

Later, carbocyanine compound JC-1 (15) was introduced to conduct real-time analyses of a-syn fibril formation. Probe $\mathbf{1 5}$ could bind to a-syn monomers as well as fibrils. Interestingly, the maximum emission wavelengths of probe $\mathbf{1 5}$ after binding to monomers and fibrils were different $(590 \mathrm{~nm}$ for monomers, 538 $\mathrm{nm}$ for fibrils), indicating that probe $\mathbf{1 5}$ is able to distinguish between monomeric and fibrillar a-syn. Furthermore, probe $\mathbf{1 5}$ did not interact with either monomeric or fibrillary $A \beta$. The high selectivity of probe $\mathbf{1 5}$ might be explained by its interaction with the acidic C-terminal region of a-syn [97]. The results also suggested that promising selective probes for a-syn may be discovered by searching for compounds that can interact with the monomeric form of a-syn, since different amyloid proteins have different primary structures but share similar beta-sheet structures once aggregated.

Some fluorescent probes previously used as sensors for other biomolecules or microenvironments were tested to monitor a-syn aggregation. One of the compounds, Coumarin 6 (16), displayed a similar sigmoidal curve as ThT when monitoring the aggregation process of a-syn. The lag phase ( $58 \mathrm{~h}$ ) was shorter than that of ThT $(74.9 \mathrm{~h})$ and the concentration required $(50 \mathrm{nM})$ was much lower than that of ThT $(10 \mu \mathrm{M})$, suggesting that probe 16 is more sensitive than ThT. The other compound 1,6-diphenyl-1,3,5hexatriene (DPH, 17), failed to show a sigmoidal curve and was believed to interact with hydrophobic environments without selectivity, while probe $\mathbf{1 6}$ could bind to the beta-sheet structure more specifically [98].

Emerging evidence indicates that a-syn oligomers are more toxic and more pathologically connected to PD than fibrils. Consequently, recent research has focused on developing 


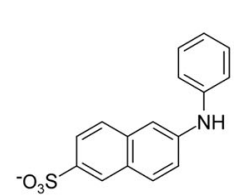

9<smiles>Cc1ccc(Nc2ccc3cc(S(=O)(=O)[O-])ccc3c2)cc1</smiles>

10

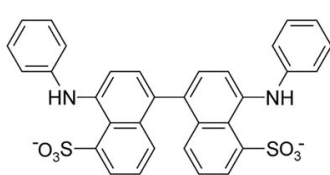

11

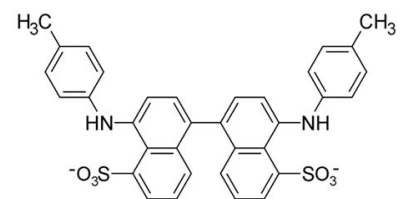

12<smiles>CCN(CC)c1ccc2c(c1)S/C(=C\c1sc3ccccc3[n+]1C)N2CC</smiles>

13<smiles>CCN(CC)c1ccc2cc(-c3nc4ccccc4s3)c(=O)oc2c1</smiles>

16

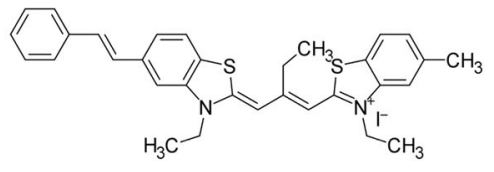

14

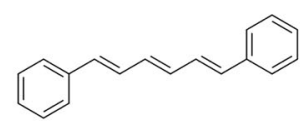

17

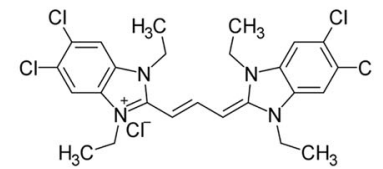

15
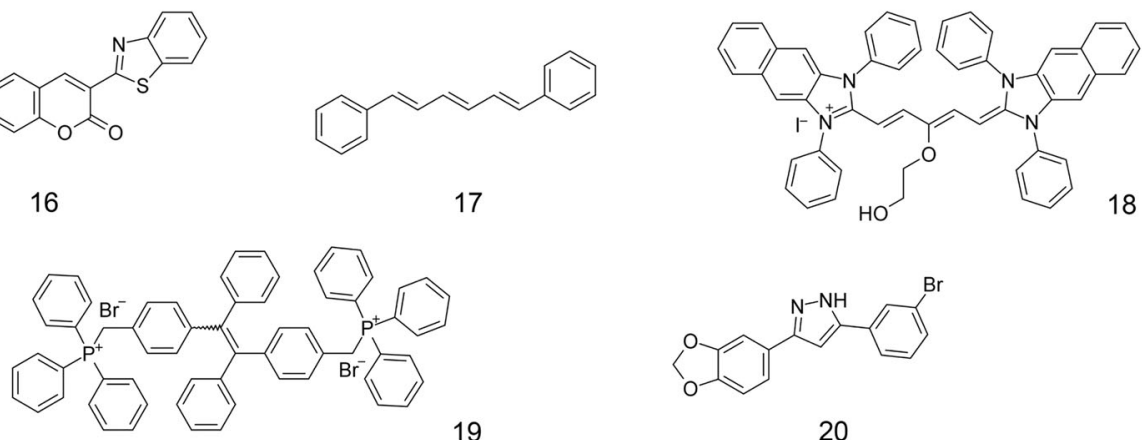

18

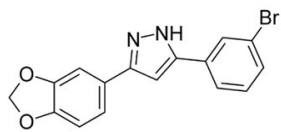

20

Fig. 3 Fluorescent probes for $\alpha$-syn

selective fluorescent dyes for oligomeric a-syn. A number of benzothiazoletrimethines and pentamethinecyanines were investigated by Kovalska and coworkers. The pentamethine cyanine dye SL-631 (18) displayed the highest selectivity for oligomeric asyn (fluorescence increase: 14.58-fold) over fibrillary a-syn (fluorescence increase: 1.88 -fold) [99]. The emission wavelength of probe $\mathbf{1 8}$ after binding to a-syn oligomers was determined to be $664 \mathrm{~nm}$, showing its potential to be used in vivo as a NIRF imaging probe. However, it remains questionable whether the bulky probe 18 could penetrate the BBB.

Another novel probe aimed at detecting a-syn oligomers is tetraphenylethene tethered with triphenylphosphonium (TPE-TPP, 19). Unlike SL-631, probe 19 is able to detect the monomeric, oligomeric and also fibrillar forms of a-syn. At the same concentration, probe 19 emitted over four times more fluorescence than ThT after incubation with a-syn fibrils. The calculated $K_{\mathrm{d}}$ for probe 19 was $4.36 \mu \mathrm{M}$, lower than that of ThT $(8.48 \mu \mathrm{M})$ [100]. Compound selectivity among different amyloids has yet to be determined. Huge challenges still exist in the discovery of probes targeting a-syn oligomers and major breakthroughs in terms of the $3 \mathrm{D}$ structure of oligomeric a-syn and the synthesis of high contrasting and selective imaging probes are urgently needed.

A known modulator of a-syn aggregation, anle138b (20), was found to exhibit a significant increase in fluorescence upon binding to a-syn fibrils with high affinity $\left(K_{d}=190 \mathrm{nM}\right)$ [101]. The study of probe $\mathbf{2 0}$ indicates not only the feasibility of discovering fluorescent probes from known inhibitors of a-syn aggregation but also the possibility of developing drugs with both therapeutic and diagnostic functions.

Until now there have not been any useful a-syn fluorescent probe reported for in vivo imaging (Table 2). In fact, the great progress made in the development of $A \beta$ fluorescent probes might negatively affect the discovery of a specific imaging probe for a-syn because naturally the same strategies to design $A \beta$ probes have been applied to the development of $a$-syn probes [102]. Since most of the existing $A \beta$ fluorescent probes share the classical push-pull structure [94], which shows little selectivity for the different amyloid protein aggregates, it has been recommended to work on novel strategies to search for or design specific ligands for a-syn.

\section{SMALL MOLECULE INHIBITORS AGAINST A-SYNUCLEIN AGGREGATION}

The idea of inhibiting a-syn aggregation, especially oligomerization, using small molecules to combat a-syn toxicity and prevent neurodegeneration has been gaining increasing attention. It has been proposed that the identification of aggregation inhibitors from screening compound libraries should be a priority [30]. Until now, a variety of small molecules have been discovered to inhibit a-syn aggregation (Table 3). In many cases, however, the inhibitory effects have also been translated to other amyloid proteins.

\section{Antibiotics}

In addition to their roles as antimicrobial agents to fight infectious diseases, antibiotics have demonstrated other properties, such as neuroprotective activity. Rifampicin (Fig. 4, 21) stabilized a-syn as a monomer and blocked the fibrillation process. Moreover, rifampicin was also able to disaggregate existing fibrils [103]. Another study confirmed the efficacy of compound $\mathbf{2 1}$ by discovering that rifampicin could prevent 1-methyl-4-phenylpyridinium $\left(\mathrm{MPP}^{+}\right)$induced toxicity in PC12 cells, increase their survival and reduce a-syn oligomer formation [104]. Another molecule tetracycline (22) is also able to inhibit the formation of fibrils and destabilize preformed fibrils. Compound $\mathbf{2 2}$ exhibited moderate effective concentrations ( $E C_{50}$ values) for the formation $(6.06 \mu \mathrm{M})$ and destabilization $(18.78 \mu \mathrm{M})$ of $a$-syn fibrils while the values for $A \beta_{1-40}$ and $A \beta_{1-42}$ were higher (10 and $10 \mu \mathrm{M}$ respectively for fibril formation; 23 and $45 \mu \mathrm{M}$ respectively, for fibril destabilization), indicating a slight selectivity for $\alpha$-syn over $A \beta$ [105].

Dopamine and its analogs

Dopamine (23) is believed to react with a-syn covalently to form asyn-quinone adducts which are primarily large molecular mass 
Table 2. Characteristics of representative fluorescent probes

\begin{tabular}{|c|c|c|c|c|c|c|}
\hline No. & $\lambda_{\mathrm{ex}} / \lambda_{\mathrm{em}}(\mathrm{nm})$ & $K_{\mathrm{d}}$ & Other targets & Scaffold & Status & Ref. \\
\hline 9 & $320 / 471^{a}, 320 / 417^{b}$ & $8.8 \mu \mathrm{M}$ & $\mathrm{N} / \mathrm{A}$ & $\mathrm{N}$-arylaminonaphthalene sulfonate & in vitro & [95] \\
\hline 10 & $320 / 475^{a}, 320 / 437^{b}$ & $11.7 \mu \mathrm{M}$ & $\mathrm{N} / \mathrm{A}$ & $\mathrm{N}$-arylaminonaphthalene sulfonate & in vitro & {$[95]$} \\
\hline 11 & $395 / 493^{b}$ & $8.6 \mu \mathrm{M}$ & $\mathrm{N} / \mathrm{A}$ & $\mathrm{N}$-arylaminonaphthalene sulfonate & in vitro & {$[95]$} \\
\hline 12 & $395 / 505^{\mathrm{b}}$ & $11.6 \mu \mathrm{M}$ & $\mathrm{N} / \mathrm{A}$ & $\mathrm{N}$-arylaminonaphthalene sulfonate & in vitro & {$[95]$} \\
\hline 13 & $443 / 580^{a}, 441 / 570^{b}$ & $0.56 \mu \mathrm{M}$ & $\mathrm{N} / \mathrm{A}$ & Monomethine cyanine & in vitro & {$[96]$} \\
\hline 14 & $562 / 568^{\mathrm{a}}, 570 / 580^{\mathrm{b}}$ & $0.65 \mu \mathrm{M}$ & $\mathrm{N} / \mathrm{A}$ & Trimethine cyanine & in vitro & {$[96]$} \\
\hline 15 & $490 / 590^{a, c}, 490 / 538^{b}$ & $2.6 \mu \mathrm{M}$ & $\mathrm{N} / \mathrm{A}$ & Carbocyanine & in vitro & {$[97]$} \\
\hline 16 & $450 / 508^{b}$ & $\mathrm{~N} / \mathrm{A}$ & Bovine carbonic anhydrase & Coumarin & in vitro & {$[98]$} \\
\hline 17 & $360 / 423^{b}$ & $\mathrm{~N} / \mathrm{A}$ & Bovine carbonic anhydrase & Hexatriene & in vitro & {$[98]$} \\
\hline 18 & $650 / 665^{\mathrm{a}}, 672 / 683^{\mathrm{b}}, 650 / 662^{\mathrm{c}}, 664 / 678^{\mathrm{d}}$ & $\mathrm{N} / \mathrm{A}$ & $\mathrm{N} / \mathrm{A}$ & Pentamethine cyanine & in vitro & [99] \\
\hline 19 & $350 / 480^{\mathrm{b}}$ & $4.36 \mu \mathrm{M}$ & $\mathrm{N} / \mathrm{A}$ & Tetraphenylethene & in vitro & {$[100]$} \\
\hline 20 & $300 / 345^{\mathrm{b}}$ & $190 \mathrm{nM}$ & $\mathrm{N} / \mathrm{A}$ & Diphenyl-pyrazole & in vitro & [101] \\
\hline
\end{tabular}

awelengths of unbound probes

bWavelengths of probes bound with $\alpha$-syn fibrils

'Wavelengths of probes bound with $\alpha$-syn monomers

dWavelengths of probes bound with $\alpha$-syn oligomers

oligomers. These oligomeric intermediates can cause cytotoxicity, implying a potential role for the interaction of compound $\mathbf{2 3}$ with asyn in PD pathogenesis [106]. However, other evidence suggests that compound $\mathbf{2 3}$ inhibits a-syn fibrillation via binding noncovalently to a-syn [107]. Based on this fact, Latawiec et al. screened 70 analogs of compound $\mathbf{2 3}$ and selected five potent compounds (24 -28) by molecular dynamics (MD) simulations. Atomic force microscopy (AFM) and transmission electron microscopy (TEM) analysis confirmed the in silico simulation predictions that the selected compounds may affect the aggregation process of a-syn [108]. The combination of in silico approaches with in vitro assays to discover ligands that interact with target proteins may emerge as a novel and efficient way to identify aggregation inhibitors for a-syn.

Dyes and pigments

Some common dyes, such as lacmoid (29), Congo red (30) and phthalocyanine tetrasulfonate (31), have been reported to inhibit a-syn fibrillation [109]. Compounds $\mathbf{2 9}$ and $\mathbf{3 0}$ were found to be nonspecific inhibitors; however, their effects were mediated by the formation of aggregates of these compounds which can interact with different regions of a-syn monomer [110]. Unlike these two nonspecific inhibitors, the inhibition of a-syn fibrillation by compound $\mathbf{3 1}$ is believed to be mediated by specific interactions with the $N$-terminus of a-syn [111]. This molecule has also been tested in animal models for the treatment of scrapie disease and exhibited anti-prion activity and showed low toxicity [112]. Therefore, compound $\mathbf{3 1}$ could be a potential therapeutic candidate for amyloid protein-related diseases. Recently, another dye, Coomassie brilliant blue R (32) not only exhibited significant inhibition of a-syn fibrillation but also prevented the formation of oligomers that caused notable neurotoxicity in cells, making it a potentially useful candidate for future in vivo studies [113]. The red blood pigment hemin (33) is a well-known inhibitor of $A \beta$ aggregation [114]. Until recently, compound $\mathbf{3 3}$ was also thought to interfere with a-syn aggregation $[115,116]$. The effects of compound $\mathbf{3 3}$ on a-syn remain controversial; however, it has not been confirmed whether compound $\mathbf{3 3}$ inhibits ThT fluorescence via inhibition of a-syn aggregation or by obstructing the interaction between ThT and the proteins [117].

Polyphenols

Polyphenols are the largest group of inhibitors of a-syn aggregation and many of them can also inhibit the aggregation of other amyloid proteins such as $A \beta$. We have categorized representative polyphenols into the following groups.

Curcuminoids. The interaction of curcumin with a-syn seems complicated in that different mechanisms of anti-aggregation by curcumin (34) have been reported. Early studies from the ThT assay and TEM showed that compound $\mathbf{3 4}$ not only inhibited the formation of a-syn fibrils but also destabilized the preformed fibrils [105]. Later, the anti-aggregation ability of compound $\mathbf{3 4}$ was confirmed by Western blot analysis and in a cell model of asyn aggregation [118]. Interestingly, another report stated that compound $\mathbf{3 4}$ does not interact with a-syn monomers but binds to oligomers and fibrils, causing morphological changes and consequently reducing their toxicity. Moreover, the interaction of compound $\mathbf{3 4}$ with early oligomers could impact the toxicity by converting the preformed oligomers into the less toxic fibrils [119]. Although compound $\mathbf{3 4}$ has been widely studied, its instability and poor bioavailability limits its medical use.

With the aim of discovering more druggable molecules with a scaffold similar to that of compound 34, Ahsan et al. first synthesized two analogs, curcumin pyrazole (35) and curcumin isoxazole. As $\mathbf{3 5}$ exhibited the most potency of inhibition of a-syn aggregation (\% inhibition of a-syn aggregation: 45.57 for 34, 37.28 for curcumin isoxazole and 62.21 for 35 ), they proceeded to synthesize 16 derivatives of $\mathbf{3 5}$. Among them, compound 6 (36) and 15 (37) showed stronger aggregation inhibition than curcumin (\% inhibition of a-syn aggregation: 90.05 for 36, 63.93 for 37). Compound 36 displayed the lowest $I C_{50}$ value $(9.21 \mu \mathrm{M})$ compared with compounds $34(161.8 \mu \mathrm{M})$ and compound 37 $(89.13 \mu \mathrm{M})$. Surprisingly, unlike compound $\mathbf{3 7}$, compound 36 failed to reduce the cytotoxicity caused by a-syn oligomers [120]. While compound $\mathbf{3 7}$ is a promising therapeutic agent for the potential treatment of PD, the case of compound $\mathbf{3 6}$ strengthens the importance of evaluating the anti-oligomerization ability of any molecules that are expected to show neuroprotection in cells and/ or animals.

Another group focused on modifications of the two aromatic rings of curcumin to increase the hydrophobicity. Of the nine reported analogs, only two (C2 and C4) showed lower stability than curcumin, and one (C3) exhibited significant cytotoxicity. Among the remaining compounds, C6 (38), which was synthesized by replacing all the hydroxyl groups of compound $\mathbf{3 4}$ with $-\mathrm{OCH}_{2} \mathrm{Ph}$ groups, showed the highest reduction in cytotoxicity 


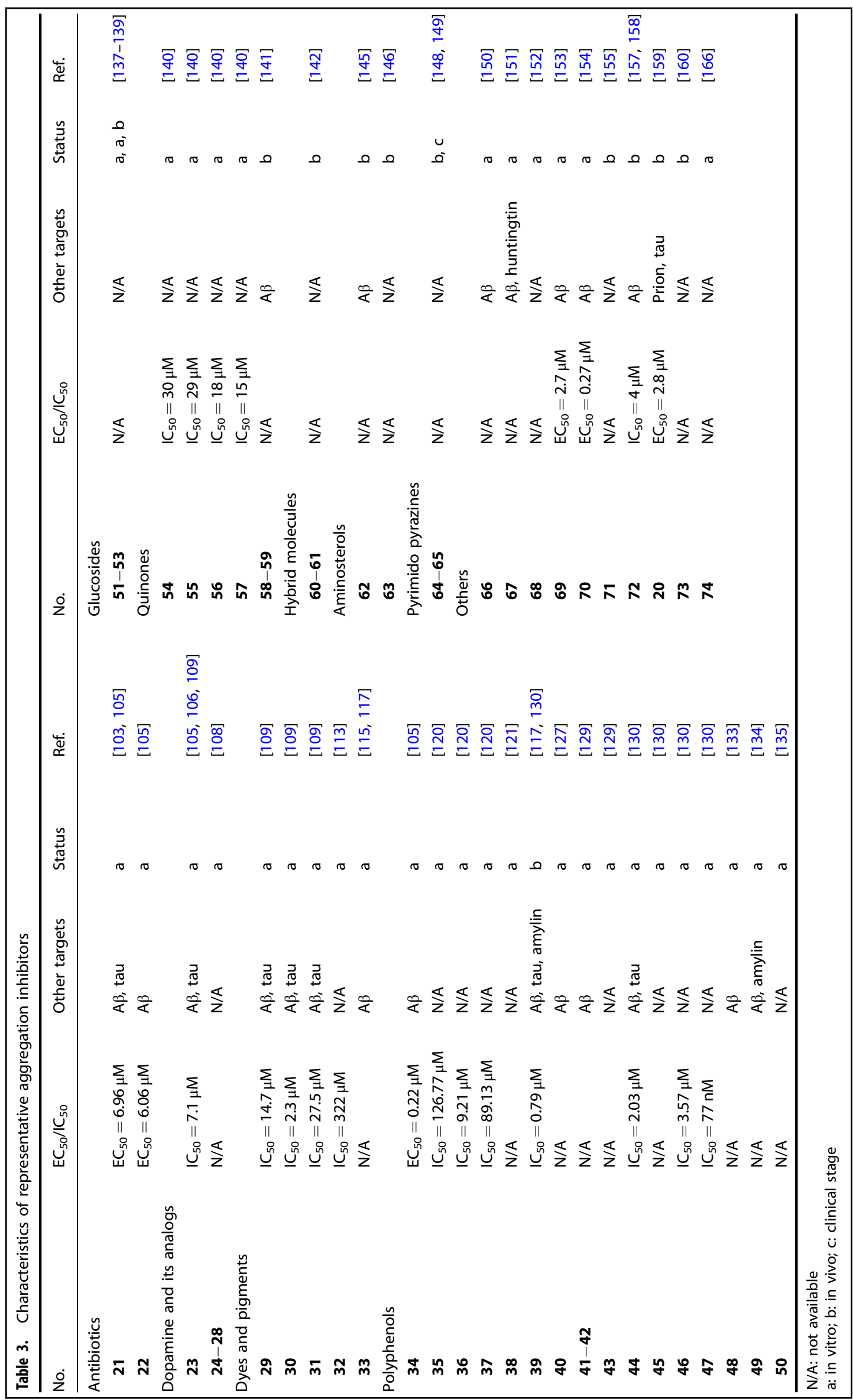




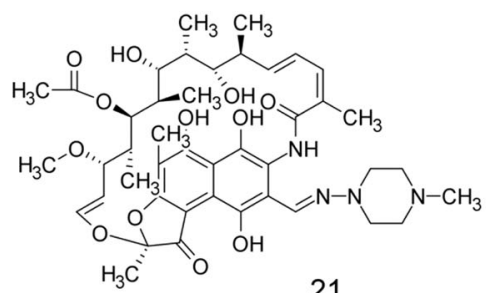

21<smiles>CN(C)C1C(O)=C(C(N)=O)C(=O)C2(O)C(O)=C3C(C)(CC12O)C(O)=C1C(=O)c2c(O)cccc2[C@@H](O)[C@@]13C</smiles>

22<smiles>NCCc1ccc(O)c(O)c1</smiles>

23<smiles>Nc1ccc2cc[nH]c2c1</smiles>

24<smiles>NCCc1ccc(O)cc1</smiles>

25<smiles>NCCc1ccc(N)cc1</smiles>

26<smiles>Oc1ccc2[nH]ccc2c1</smiles>

27<smiles>CC(C)(C)c1ccc(O)c(N)c1</smiles>

28<smiles>Nc1cc2oc3cc(=O)c(-c4ccc(O)cc4O)cc-3nc2cc1-c1ccc(O)cc1O</smiles>

29<smiles>Nc1ccc(-c2ccc(N=Nc3cc(S(=O)(=O)O[Na])c4ccccc4c3N)cc2)cc1</smiles>

30<smiles>Nc1cc(S(=O)(=O)O[Na])c2ccccc2c1N</smiles>

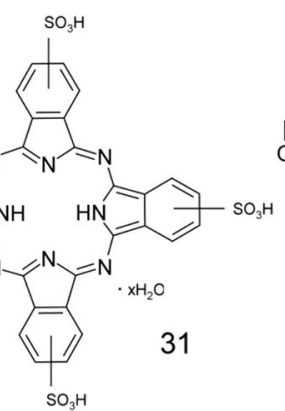<smiles>CCOc1ccc(Nc2ccc(C(=C3C=CC(=[N+](CC)Cc4cccc(S(=O)(=O)[O-])c4)C=C3)c3ccc(N(CC)Cc4cccc(S(=O)(=O)[O-])c4)cc3)cc2)cc1</smiles>

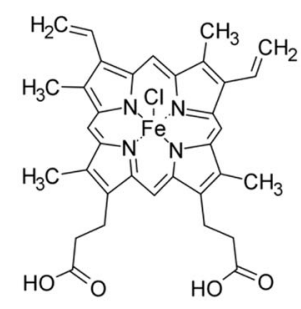<smiles>COc1cc(/C=C/c2cc(/C=C/c3ccc(O)c(OC)c3)n(-c3cccc(F)c3)n2)ccc1O</smiles>

34<smiles>COc1cc(/C=C/C(=O)/C=C(O)/C=C/c2ccc(O)c(OC)c2)ccc1O</smiles><smiles>COc1cc(/C=C/C2CC(/C=C/c3ccc(O)c(OC)c3)NN2)ccc1O</smiles>

35

36<smiles>C=CCn1nc(/C=C/c2ccc(O)c(OC)c2)cc1/C=C/c1ccc(O)c(OC)c1</smiles><smiles>COc1cc(/C=C/C(=O)CC(=O)/C=C/c2ccc(OCc3ccccc3)c(OC)c2)ccc1OCc1ccccc1</smiles>

38

37

Fig. 4 Aggregation inhibitors for $\alpha$-syn (compounds 21-38)

caused by the preformed oligomers and fibrils. Consistent with previous study [119], curcumin and its analog compound $\mathbf{3 8}$ were found to accelerate the process of a-syn aggregation into less toxic fibrils [121].

Flavanols. The green tea polyphenol EGCG (Fig. 5, 39) is perhaps the most studied inhibitor of aggregation of different amyloid proteins. It is also a common positive control in many studies aiming to develop new anti-amyloidogenic molecules. Ehrnhoefer et al. demonstrated that compound 39 can directly bind to monomeric a-syn and promote the formation of unstructured, nontoxic a-syn oligomers. NMR results suggested that the compound 39 binds randomly to the backbone of a-syn [122], which, along with another report using MS to study the binding of compound 39 with a-syn [123], may explain why the effects of compound $\mathbf{3 9}$ on a-syn can also be seen on $A \beta$. Additionally, compound $\mathbf{3 9}$ is able to bind to preformed a-syn fibrils $\left(K_{\mathrm{d}}=100 \mathrm{nM}\right)$ and transform them into smaller amorphous aggregates that are less toxic [124]. However, the mechanism by which compound 39 reduces the toxicity of a-syn oligomers is not the same as in the case of fibrils. One group found that treatment with compound $\mathbf{3 9}$ does not cause notable changes in the structure or size of a-syn oligomers. Instead, the binding of compound 39 to a-syn oligomers prevents permeabilization of the a-syn oligomers with cell membranes, thus reducing the toxicity [125]. In animal studies, tea polyphenols mainly containing compound $\mathbf{3 9}$ were reported to reduce the level of a-syn oligomers in a PD monkey model [126].

Theaflavins, which are abundant in black tea, exert antiamyloidogenic effects in the same way as compound 39, promoting the assembly of monomeric $\alpha$-syn and $A \beta$ into nontoxic aggregates and converting the preformed fibrils into nontoxic aggregates [127]. Nevertheless, the tendency of compound 39 and theaflavins to be oxidized could compromise their 
<smiles>O=C(O[C@H]1Cc2c(O)cc(O)cc2O[C@H]1c1cc(O)c(O)c(O)c1)c1cc(O)c(O)c(O)c1</smiles>

39<smiles></smiles><smiles>O=c1cc(-c2ccc(O)cc2)oc2cc(O)c(O)c(O)c12</smiles>

45<smiles>C/C=C1/C(O)OC=C(C(=O)OC)C1CC(=O)OCc1ccc(O)c(O)c1</smiles><smiles>OCCc1ccc(O)c(O)c1</smiles>

49<smiles></smiles>

46<smiles>O=C(/C=C/c1ccc(O)cc1)c1ccc(O)cc1O</smiles>

41<smiles>Oc1cc(O)cc(C=Cc2ccc(O)c(O)c2)c1</smiles>

42<smiles>CC(Cc1ccc(O)c(O)c1)C(C)Cc1ccc(O)c(O)c1</smiles>

47<smiles>O=C1c2c(O)cc(O)cc2O[C@H](c2cc(O)c(O)c(O)c2)[C@@H]1O</smiles>

43<smiles>O=c1cc(-c2ccccc2)oc2cc(O)c(O)c(O)c12</smiles>

44<smiles>O=C(O)c1ccc(O)c(O)c1</smiles>

48

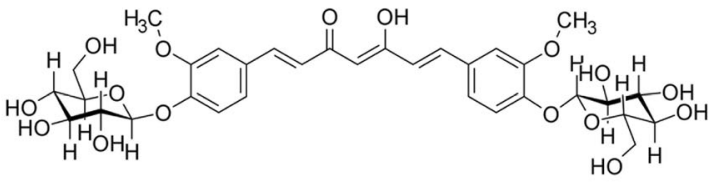

51

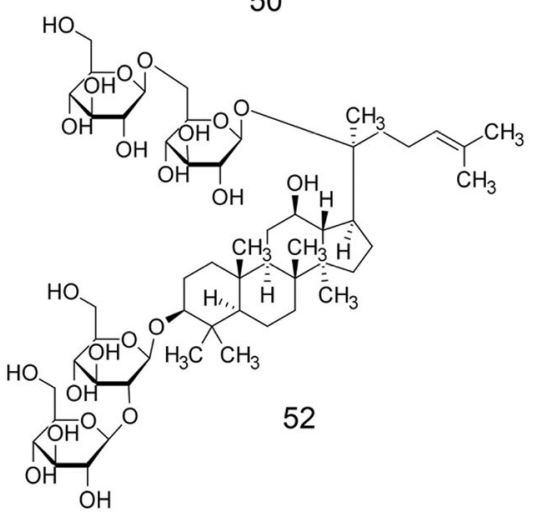<smiles>O=C1CC(c2ccc(OC3OC(CO)C(O)C(O)C3O)cc2)Oc2cc(O)ccc21</smiles>

53

Fig. 5 Aggregation inhibitors for $\alpha$-syn (compounds 39-53)

ability to inhibit amyloidogenesis. Although preoxidized compound 39 is still able to significantly inhibit the aggregation process, a reduction in efficacy can be seen after long-term preoxidation in the case of compound $\mathbf{3 9}$ but not in the case of another theaflavin, TF3 (40), which is less rapidly oxidized than EGCG [127]. These results suggest that the anti-amyloidogenic abilities of common polyphenols may partially depend on the antioxidant properties. Developing polyphenols that are resistant to oxidation, such as compound $\mathbf{4 0}$, may help to discover promising therapeutic agents for amyloid protein-related disease.

Stilbenes. Previous evidence has demonstrated that some stilbenes can inhibit $A \beta$ aggregation [128]. To explore the potential application of stilbenes in the discovery of inhibitors for a-syn aggregation, Temsamani et al. studied three wine stilbenes, piceatannol (41), ampelopsin A (42) and isoheopeaphenol (43). Although all three stilbenes inhibited fibrillation, only compound 41 showed notable protection of cells treated with a-syn aggregates [129]. An explanation for this may be that compound $\mathbf{4 1}$ is also able to disaggregate preformed fibrils, and its relatively small size could enable compound $\mathbf{4 1}$ to easily penetrate the cell membrane to exert its protective effects.

Other phenolic compounds. Using confocal single-particle fluorescence techniques, Caruana et al. investigated the effects of different polyphenolic compounds. In addition to the abovementioned theaflavins and compound 39, they also studied flavones (apigenin, baicalein and scutellarein), flavonols (myricetin and quercetin), phenolic acids (rosmarinic acid and tannic acid), a stilbene (resveratrol) and others (ginkgolide $B$, nordihydroguaiaretic acid). The most potent compounds, baicalein (44), scutellarein (45), myricetin (46), compound 39, nordihydroguaiaretic acid (47) and black tea extract (mainly theaflavins), were selected because they exhibited significant inhibition and disaggregation of a-syn at 
low concentrations $\left(\mathrm{IC}_{50}<4 \mu \mathrm{M}\right)$. The structure activity relationship (SAR) study suggested that aggregation inhibitors should contain aromatic rings for interactions with monomeric and oligomeric a-syn and adjacent hydroxyl groups on the same ring [130]. Moreover, the authors proposed that the selected compound would be promising for tests in PD animal models. In addition to compound 39, compound $\mathbf{4 4}$ has also been studied in vivo and should be considered a potential drug candidate for clinical trials. In $\mathrm{MPP}^{+}$-treated SD rats, compound $\mathbf{4 4}$ reduced the increase of a-syn aggregates and protected the nigrostriatal dopaminergic system in the brain [131]. Similar effects from compound 44 were observed in the rotenone mouse model, where a-syn oligomers greatly decreased the striatal neurotransmitters, including dopamine, and rotenone-associated behavioral dysfunction was improved [132].

As a main metabolite of green tea polyphenols, protocatechuic acid (48) is able to inhibit a-syn aggregation, disaggregate preformed a-syn fibrils and protect PC12 cells from toxicity caused by a-syn aggregates [133]. However, this phenolic acid can also exert similar effects on $A \beta$. Oleuropein aglycone (49), which is commonly found in olive oil, was found to protect SH-SY5Y cell viability via stabilization of a-syn in the monomeric state, directing a-syn to form nontoxic aggregates and obstructing the binding of a-syn to cell membranes [134]. Another a-syn aggregation inhibitor discovered from olives is hydroxytyrosol (50). Similar to compound $\mathbf{4 8}$, compound $\mathbf{5 0}$ can also inhibit a-syn aggregation and destabilize preformed a-syn fibrils. Notably, compound $\mathbf{5 0}$ at a concentration of $25 \mu \mathrm{M}$ almost completely reversed the toxicity caused by a-syn aggregates [135] while compound $\mathbf{4 8}$ only rescued the cell viability to approximately $80 \%$ at the same concentration [133]. The discovery of active anti-amyloidogenic compounds from olive indicates another good dietary source that may help to prevent neurodegenerative diseases, in addition to green tea.

\section{Glucosides}

Glucosylation of common organic compounds may help to increase their bioavailability [136]. Curcumin-glucoside (51), which was synthesized by replacing the two hydroxyl groups on the aromatic rings with glucose moieties, showed similar effects to inhibit a-syn oligomerization as well as to destabilize preformed fibrils compared with compound $\mathbf{3 4}$ but was believed to be more potent. Importantly, the introduction of glucose increased the solubility [137]. There are also natural glycosides that have been reported to be anti-amyloidogenic agents. One common group is ginsenosides, the main biologically active extract from ginseng. $\mathrm{Rb} 1$ (52) is one of the most studied ginsenosides and can inhibit oligomerization and fibrillation as well as disaggregate preformed fibrils. Administration of compound $\mathbf{5 2}$ in cells can significantly attenuate the toxicity induced by a-syn aggregates, thus making it worthwhile for compound $\mathbf{5 2}$ to be further tested in animal models [138]. Another glucoside, liquiritin (53), comes from Glycyrrhizauralensis, a common traditional Chinese medicine for the treatment of PD. In vitro studies have demonstrated that compound $\mathbf{5 3}$ can inhibit both oligomerization and fibrillation of a-syn. In a transgenic $C$. elegans expressing human a-syn, compound $\mathbf{5 3}$ significantly inhibited a-syn aggregation and extended the life span of the treated worms [139].

\section{Quinones}

It has been reported that several vitamins $\mathrm{K}$, unlike many promiscuous inhibitors that bind to a-syn via nonspecific hydrophobic interactions, can inhibit a-syn fibrillation and disassemble preformed fibrils by specifically binding to the $N$ terminal region of a-syn. These vitamins (Fig. 6, phylloquinone, 54, menaquinone, $\mathbf{5 5}$ and menadione, 56) are actually derivatives of 1,4-naphthoquinone (1,4-NQ, 57), indicating a potential role for the scaffold of compound $\mathbf{5 7}$ in the design of novel specific inhibitors for a-syn [140]. Interactions of these vitamins $\mathrm{K}$ with other amyloid proteins have yet to be explored.

Tanshinone I (58) and tanshinone II A (59) are the main active components in the traditional Chinese medicine Danshen. Similar to EGCG, these two phenanthrenequinones have been demonstrated to reduce the formation of a-syn oligomers and fibrils as well as destabilize the preformed fibrils. The benefits of these two molecules were further confirmed in a dye leakage assay where they managed to prevent the membrane damage caused by a-syn aggregates. The good performance in vitro paved the way for later in vivo assays conducted in a $C$. elegans model expressing a-syn. Compounds 58 and 59 both significantly prevented a-syn aggregation and extended the life span of treated $C$. elegans [141]. Since other neuroprotective effects of these compounds have already been studied in different rodent models, compounds $\mathbf{5 8}$ and $\mathbf{5 9}$ are expected to target a-syn aggregation in PD rodent models.

\section{Hybrid molecules}

In light of the complex pathogenesis of PD, designing molecules that are capable of targeting different factors related with the disease is an attractive approach. Compounds $18(60)$ and 24 (61), which are 3-arylcoumarin-tetracyclic tacrine derivatives, were synthesized and selected as promising leads for the further development of potential PD therapeutics. Consistent with the design strategy, these two compounds exhibited multitargeted properties, including inhibition of a-syn aggregation, antioxidation and enhancement of the content of dopamine [142]. The concept of designing hybrid compounds for multitargeted functions may contribute to discovering novel therapeutics for future PD treatment.

\section{Aminosterol}

It has been found that lipid vesicles can assist the nucleation of monomeric a-syn, which is a key step in a-syn aggregation [143]. The potential effects of the aminosterol compound squalamine (62) on a-syn aggregation was studied as this compound is able to translocate proteins from the cell membrane to the cytoplasm [144]. In an a-syn aggregation system containing lipid vesicles, compound $\mathbf{6 2}$ intervened in the interaction between a-syn and the surface of the vesicles, thereby inhibiting a-syn aggregation [145]. This mechanism of compound $\mathbf{6 2}$ also counteracted the toxicity of oligomeric a-syn in SH-SY5Y cells, reduced a-syn aggregation and alleviated the immobility caused by a-syn aggregates in C. elegans overexpressing a-syn [145]. Later, the same group studied another structurally similar compound, trodusquemine (63). The side chain of compound 63 is spermine rather than spermidine as in compound $\mathbf{6 2}$. The introduction of additional positive charges was attributed to the increased ability of compound $\mathbf{6 3}$ to displace a-syn from both lipid vesicles and preformed a-syn fibrils, thus making this aminosterol able to inhibit not only the nucleation of a-syn monomers but also fibrilinduced aggregation [146]. Like compound 62, compound 63 also protected SH-SY5Y cells from the toxicity of oligomeric a-syn and improved the fitness of $C$. elegans overexpressing a-syn [146]. Future investigations of these two aminosterols in rodent PD models are anticipated.

\section{Pyrimido pyrazine}

Targeting the interaction between a-syn and membranes has become an important therapeutic strategy for synucleinopathies [147]. While the aforementioned aminosterols are molecules isolated from nature, Neuropore Therapies, Inc. along with its collaborators developed a promising compound, NPT100-18A (64), a de novo synthesized molecule with a pyrimido pyrazine scaffold. Compound 64 was designed to target the 96-102 domain of a-syn that is believed to mediate the dimerization of a-syn on membranes [148]. By inhibiting the interaction between 
<smiles>CC(=CCC1=C(C)C(=O)c2ccccc2C1=O)CCCC(C)CCCC(C)CCCC(C)C</smiles><smiles>CC(C)=CCC/C(C)=C/CC/C(C)=C/CC/C(C)=C/CC1=C(C)C(=O)c2ccccc2C1=O</smiles><smiles>CC1=CC(=O)c2ccccc2C1=O</smiles>

56<smiles>O=C1C=CC(=O)c2ccccc21</smiles>

57<smiles>Cc1coc2c1C(=O)C(=O)c1c-2ccc2c(C)cccc12</smiles>

58<smiles>Cc1coc2c1C(=O)C(=O)c1c-2ccc2c1CCCC2(C)C</smiles>

59<smiles>COc1cc(-c2cc3cc(C4C5=C(CCCC5=O)Oc5nc6c(c(N)c54)CCCC6)cc(C(C)C)c3oc2=O)cc(OC)c1OC</smiles><smiles>CCC(C)c1cc(C2C3=C(CCCC3=O)Oc3nc4c(c(N)c32)CCCC4)cc2cc(-c3cc(OC)c(OC)c(OC)c3)c(=O)oc12</smiles>

61<smiles>CC(C)C(CC[C@@H]1CC[C@H]2[C@@H]3[C@H](CC[C@]12C)[C@@]1(C)CC[C@H](NCCCNCCCCN)C[C@@H]1C[C@H]3O)OS(=O)(=O)O</smiles>
60

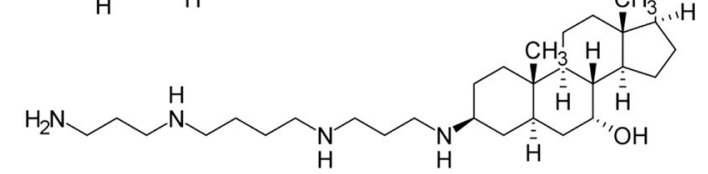<smiles>CCCCC1C(=O)N(CC2CCNCC2)CC2N(C(=O)CCc3c[nH]c4ccccc34)CCC(=O)N12</smiles><smiles>COc1ccc2[nH]cc(CCNC(C)=O)c2c1</smiles>

69<smiles>C#CCN(C)[C@@H](C)Cc1ccccc1</smiles>

70<smiles>OC1[C@H](O)C(O)[C@@H](O)[C@H](O)[C@H]1O</smiles>

67<smiles>CCCCCC(O)/C=C/C=O</smiles>

66<smiles>N#Cc1c(O)nc(-c2cccc([N+](=O)[O-])c2)c([N+](=O)[O-])c1C(F)(F)F</smiles>

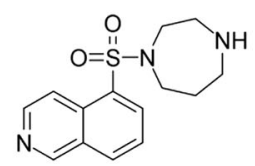

73<smiles>[X][M]C1C=C(C(=O)O)Nc2c(C(=O)Nc3cccc(OC)c3)cnn21</smiles>

$\mathrm{HO}$<smiles>Cc1cc(O)c2c(c1)Oc1c(O)cc(O)c(Oc3cc(O)c(O)c(O)c3)c1Oc1c(O)cc(O)cc1O2</smiles>

68<smiles>CC(O)=CC(C)=CO</smiles>

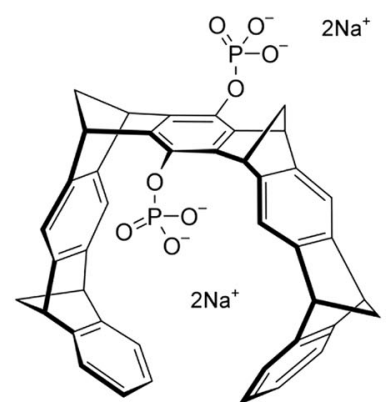

72

Fig. 6 Aggregation inhibitors for $\alpha$-syn (compounds 54-64. 66-74)

a-syn and lipid membranes, compound 64 reduced the formation of toxic a-syn oligomers in primary rat neurons. The long-term effects of compound $\mathbf{6 4}$ in a wild-type a-syn transgenic mouse model improved the performance of treated mice in motor behavioral assessments [148]. In the brains of these treated mice, the accumulation of a-syn was significantly reduced in different regions (neocortex, hippocampus, and striatum). A reduction in a-syn was also seen in the substantia nigra but this result was not significant. Sodium dodecyl sulfate polyacrylamide gel electrophoresis (SDS-PAGE) demonstrated that compound $\mathbf{6 4}$ decreased 
the amount of a-syn dimers and oligomers, a phenomenon that was also seen in an oligomer-prone E57K a-syn transgenic mouse model [148]. Pathologically, neuronal death, synapto-dendritic damage and astrogliosis were notably improved, indicating an association between inhibition of a-syn accumulation, recovered neurodegeneration, and ameliorated motor function [148]. The short-term effects of compound $\mathbf{6 4}$ were evaluated in real time in a-syn-GFP transgenic mice. The reduction of the a-syn-GFP signal at synapses could be seen between 30 and $60 \mathrm{~min}$ after administration, indicating the efficiency of compound 64 to inhibit a-syn accumulation at synaptic terminals [148].

Compound 64 suffered from poor oral bioavailability and poor brain penetration; therefore, this compound was not advanced further for clinical studies [149]. Based on the structure of compound 64, a new compound, NPT200-11 (65), with improved pharmacokinetic properties, was introduced. Compound $\mathbf{6 5}$ maintained similar efficacies compared to compound 64, including a decrease in a-syn accumulation, amelioration of neurodegenerative pathology and improvements in behavioral performance [149]. According to the authoritative database of clinical trials (ClinicalTrials.gov), the phase 1 study of compound 65 in healthy subjects was successfully completed in 2016. A phase $1 \mathrm{~b}$ clinical study in both healthy subjects and PD patients is expected to be conducted in Europe. Without a doubt, compound $\mathbf{6 5}$ is the most promising small molecule drug candidate targeting a-syn aggregation.

\section{Others}

There are still many other molecules that have been reported to be inhibitors of a-syn aggregation at the molecular level, such as aldehyde 4-hydroxy-2-nonenal (HNE, 66) [150] and scyllo-inositol (67) [151]. Compound 66 has perhaps the simplest structures among all the reported inhibitors since it has no aromatic ring and the molecular mass is only $156 \mathrm{Da}$. Compound $\mathbf{6 7}$ is already well known for its efficacy to inhibit $A \beta$ aggregation in vitro and in vivo.

In cell models, compounds such as dieckol (68) [152], melatonin (69) [153], selegiline (70) [154], and synuClean-D (71) [155] can exert neuroprotection against toxicity induced by a-syn aggregates. The discovery of compound $\mathbf{7 1}$ resulted from drug screening based on the ThT assay [156]. The ameliorative effects of compound $\mathbf{7 1}$ were also observed in PD C. elegans models. Treatment with compound $\mathbf{7 1}$ remarkably reduced the formation of a-syn aggregates and protected dopaminergic cells from death in C. elegans, attributing to the improved motility [155].

The following three molecules are promising compounds to be further developed into useful PD disease-modifying drugs for clinical applications. The first one, CLR01 (72), also termed molecular tweezer, was first studied systematically by Prabhudesai et al. In vitro assays including ThT assays and TEM demonstrated that compound $\mathbf{7 2}$ can inhibit a-syn aggregation as well as disassemble preformed fibrils. Compound $\mathbf{7 2}$ also exhibited significant protection in both HEK293 cells expressing a-syn endogenously and PC12 cells treated with aggregated a-syn. Excitingly, compound $\mathbf{7 2}$ managed to reduce apoptosis induced by a-syn aggregation in zebra fish embryos expressing a-syn, which contributed to increased survival of the treated embryos [157]. Both intracerebroventricular and subcutaneous administration of compound $\mathbf{7 2}$ to mice overexpressing a-syn can notably alleviate the motor deficits caused by a-syn pathology and is accompanied by a decrease in the soluble a-syn fraction. The long-term efficacy of compound $\mathbf{7 2}$ could be explained by its stable kinetics in vivo [158]. Modifications of this molecule to increase its ability to penetrate the BBB would be required before moving to human trials.

Anle138b (20) was discovered by a high-throughput screening system against the aggregation of the prion protein. Interestingly, compound $\mathbf{2 0}$ is also able to reduce the formation of a-syn oligomers. Administration of compound $\mathbf{2 0}$ in the rotenone mouse model successfully ameliorated motor dysfunction. In another transgenic mouse model expressing human A30P mutated a-syn, compound $\mathbf{2 0}$ was shown to improve motor performance, prevent the spread of deposited a-syn in the brain and reduce the level of a-syn oligomers [159]. Since compound 20 possesses ideal pharmacokinetic properties, it would not take long for it to be tested clinically to treat PD and prion diseases.

The identification of fasudil (73) as a potent inhibitor of a-syn aggregation is quite exciting, as it is already an approved drug for cerebral vasospasm. Therefore, it would not be difficult for compound $\mathbf{7 3}$ to be used clinically in the future for treatment of PD given that this molecule can effectively inhibit a-syn aggregation via specific binding to the C-terminal region and more importantly, treatment with compound $\mathbf{7 3}$ can improve motor performance and recognition memory in a-syn A53T mutated mice [160].

\section{CONCLUSIONS AND FUTURE PERSPECTIVES}

Lewy bodies were first identified over 100 years ago and their main component, a-syn, though seemingly discovered much later, has been investigated for over 20 years. It is believed that the aggregation process of a-syn plays a central role in PD pathogenesis and as a result, the past decade has seen a large number of studies focusing on a-syn aggregation and its role as a biomarker.

A variety of small molecule probes and inhibitors of a-syn have been developed over the past decade. Some of these inhibitors have been tested in vivo and therefore are promising candidates for clinical trials. Many of the discovered molecules are also able to affect the aggregation of other amyloid proteins, indicating their roles as nonspecific amyloid inhibitors. The reason for this may be explained by discussing the common techniques for the discovery of molecules capable of interacting with a-syn.

Similar to other biophysical techniques, ThT assays are not able to sensitively detect and individually characterize unique protein subspecies with which a small molecule ligand interacts [161]. A ThT assay can also be compromised if the small molecule can competitively bind to the dye-binding site on the protein or quench the emission of fluorescence via interaction with the dye [162].

The advantages of mass spectrometry (MS) over other screening assays include the rapid discovery of candidate inhibitors and, more importantly, the ability to identify binding modes and the particular protein conformations responsible for the interactions with the small molecules [116, 117, 163]. Based on previous studies, we have recently established an automated screening system for screening scaffolds that can bind to monomeric a-syn. By screening over 2500 pure compounds, we identified a new asyn aggregation inhibitor (74) with a pyrazolo [1, 5-a] pyrimidine5- carboxylic acid scaffold. This molecule exhibited similar effects in the ThT assay and circular dichroism (CD) and TEM experiments with the positive controls EGCG and hemin. Coincubation of a-syn with compound $\mathbf{7 4}$ protected $\mathrm{SH}-\mathrm{SY} 5 \mathrm{Y}$ cells from the toxicity of a-syn aggregates. MS techniques also allow the electron capture dissociation (ECD) fragmentation of the protein-ligand complexes, which can offer information about the binding regions of the ligands [164, 165]. Compound 74 displayed a more specific binding region on the primary sequence of monomeric a-syn and a clear binding preference for low-charge states, suggesting its higher selectivity for monomeric a-syn than EGCG and hemin [166].

In an endeavor to discover specific a-syn aggregation inhibitors, research has started to focus on developing molecules that target specific regions of monomeric a-syn, such as vitamins $(\mathbf{5 4}, \mathbf{5 5}$ and 56) [140] and the two de novo synthesized pyrimido pyrazine derivatives (64 and 65) [148, 149]. The ability to detect the interactions between small molecules and monomeric a-syn 
makes MS a powerful technique to discover specific a-syn binding compounds and identify the specific regions to which the compounds bind. We also propose that the a-syn binding scaffolds screened by MS have the potential to be further developed into both fluorescent and PET imaging probes. This means that a single molecule may have both therapeutic and diagnostic functions. These types of theranostic reagents have already been investigated for cancer [167] and AD [168] and we believe that developing molecules with theranostic functions for PD will become a hot topic in the near future.

\section{ACKNOWLEDGEMENTS}

This work was supported by the Griffith University International Postgraduate Research Scholarship (GUIPRS) and the Griffith University Postgraduate Research Scholarship (GUPRS). The authors also want to thank Dr. Stephen Wood and Dr. Alex Sykes for their helpful discussions and proofreading of this paper.

\section{AUTHOR CONTRIBUTIONS}

MMX wrote the paper; PR, SR, RJQ, HYZ and GDM read and revised the paper.

\section{ADDITIONAL INFORMATION}

Competing interests: The authors declare no competing interests.

\section{REFERENCES}

1. Jankovic J. Parkinson's disease: clinical features and diagnosis. J Neurol Neurosurg Psychiatry. 2008;79:368-76.

2. Chaudhuri KR, Healy DG, Schapira AH. Non-motor symptoms of Parkinson's disease: diagnosis and management. Lancet Neurol. 2006;5:235-45.

3. Meissner WG, Frasier M, Gasser T, Goetz CG, Lozano A, Piccini P. et al. Priorities in Parkinson's disease research. Nat Rev Drug Discov. 2011;10:377-93.

4. Lashuel HA, Overk CR, Oueslati A, Masliah E. The many faces of alpha-synuclein: from structure and toxicity to therapeutic target. Nat Rev Neurosci. 2013;14:38-48.

5. German DC, Manaye K, Smith WK, Woodward DJ, Saper CB. Midbrain dopaminergic cell loss in Parkinson's disease: computer visualization. Ann Neurol. 1989;26:507-14

6. Lewy F. Paralysis agitans. I. Pathologische anatomie. Handb der neurologie. 1912;3:920-58.

7. Trétiakoff $C$. Contribution à l'étude de l'anatomie pathologique du locus niger de Soemmering avec quelques déductions relatives à la pathogénie des troubles du tonus musculaire et de la maladie de Parkinson. Université de Paris, Paris; 1919.

8. Hughes AJ, Daniel SE, Kilford L, Lees AJ. Accuracy of clinical diagnosis of idiopathic Parkinson's disease: a clinico-pathological study of 100 cases. J Neurol Neurosurg Psychiatry. 1992;55:181-4.

9. Gelb DJ, Oliver E, Gilman S. Diagnostic Criteria for Parkinson Disease. Arch Neurol. 1999;56:33-9.

10. Postuma RB, Berg D, Stern M, Poewe W, Olanow CW, Oertel W, et al. MDS clinical diagnostic criteria for Parkinson's disease. Mov Disord. 2015;30:1591-601.

11. Hughes AJ, Daniel SE, Lees AJ. Improved accuracy of clinical diagnosis of Lewy body Parkinson's disease. Neurology. 2001;57:1497-9.

12. Rizzo G, Copetti M, Arcuti S, Martino D, Fontana A, Logroscino G. Accuracy of clinical diagnosis of Parkinson disease: a systematic review and meta-analysis. Neurology. 2016;86:566-76.

13. Sawle GV, Playford ED, Burn DJ, Cunningham VJ, Brooks DJ. Separating Parkinson's disease from normality: discriminant function analysis of fluorodopa $F$ 18 positron emission tomography data. Arch Neurol. 1994;51:237-43.

14. Ohtsuka C, Sasaki M, Konno K, Koide M, Kato K, Takahashi J, et al. Changes in substantia nigra and locus coeruleus in patients with early-stage Parkinson's disease using neuromelanin-sensitive MR imaging. Neurosci Lett. 2013:541:93-8

15. Politis M. Neuroimaging in Parkinson disease: from research setting to clinical practice. Nat Rev Neurol. 2014;10:708-22.

16. Hawkes $\mathrm{CH}$. The prodromal phase of sporadic Parkinson's disease: does it exist and if so how long is it? Mov Disord. 2008;23:1799-807.

17. Hawkes CH, Del Tredici K, Braak H. A timeline for Parkinson's disease. Parkinsonism Relat Disord. 2010;16:79-84.

18. Braak H, Del Tredici K. Invited Article: Nervous system pathology in sporadic Parkinson disease. Neurology. 2008;70:1916-25.
19. Del Tredici K, Braak H. A not entirely benign procedure: progression of Parkinson's disease. Acta Neuropathol. 2008;115:379-84.

20. Braak H, Del Tredici K, Rüb U, De Vos RA, Steur ENJ, Braak E. Staging of brain pathology related to sporadic Parkinson's disease. Neurobiol Aging. 2003;24:197-211.

21. Youdim MB, Geldenhuys WJ, Van der Schyf CJ. Why should we use multifunctional neuroprotective and neurorestorative drugs for Parkinson's disease? Parkinsonism Relat Disord. 2007;13:S281-S91.

22. Van der Schyf CJ, Geldenhuys WJ. Multimodal drugs and their future for Alzheimer's and Parkinson's disease. Int Rev Neurobiol. 2011;100:107-25.

23. Van der Schyf CJ. Rational drug discovery design approaches for treating Parkinson's disease. Expert Opin Drug Discov. 2015;10:713-41.

24. Uéda $K$, Fukushima $H$, Masliah $E$, Xia $Y$, Iwai $A$, Yoshimoto $M$, et al. Molecular cloning of cDNA encoding an unrecognized component of amyloid in Alzheimer disease. Proc Natl Acad Sci USA. 1993;90:11282-6.

25. Clayton DF, George JM. The synucleins: a family of proteins involved in synaptic function, plasticity, neurodegeneration and disease. Trends Neurosci. 1998;21:249-54.

26. Hong DP, Xiong W, Chang JY, Jiang C. The role of the C-terminus of human asynuclein: intra-disulfide bonds between the C-terminus and other regions stabilize non-fibrillar monomeric isomers. FEBS Lett. 2011;585:561-6.

27. Dettmer U, Newman AJ, Luth ES, Bartels T, Selkoe D. In vivo cross-linking reveals principally oligomeric forms of a-synuclein and $\beta$-synuclein in neurons and nonneural cells. J Biol Chem. 2013;288:6371-85.

28. Luth ES, Bartels T, Dettmer U, Kim NC, Selkoe DJ. Purification of a-synuclein from human brain reveals an instability of endogenous multimers as the protein approaches purity. Biochemistry. 2014;54:279-92.

29. Bartels T, Choi JG, Selkoe DJ. a-Synuclein occurs physiologically as a helically folded tetramer that resists aggregation. Nature. 2011;477:107-10.

30. Dehay B, Bourdenx M, Gorry P, Przedborski S, Vila M, Hunot S, et al. Targeting asynuclein for treatment of Parkinson's disease: mechanistic and therapeutic considerations. Lancet Neurol. 2015;14:855-66.

31. Abeliovich A, Schmitz Y, Fariñas I, Choi-Lundberg D, Ho WH, Castillo PE, et al. Mice lacking a-synuclein display functional deficits in the nigrostriatal dopamine system. Neuron. 2000;25:239-52.

32. Cabin DE, Shimazu K, Murphy D, Cole NB, Gottschalk W, Mcllwain KL, et al. Synaptic vesicle depletion correlates with attenuated synaptic responses to prolonged repetitive stimulation in mice lacking a-synuclein. J Neurosci. 2002;22:8797-807.

33. Iwai A, Masliah E, Yoshimoto M, Ge N, Flanagan L, De Silva HR, et al. The precursor protein of non-A $\beta$ component of Alzheimer's disease amyloid is a presynaptic protein of the central nervous system. Neuron. 1995;14:467-75.

34. Withers GS, George JM, Banker GA, Clayton DF. Delayed localization of synelfin (synuclein, NACP) to presynaptic terminals in cultured rat hippocampal neurons. Brain Res Dev Brain Res. 1997:99:87-94.

35. Kahle PJ, Neumann M, Ozmen L, Müller V, Jacobsen $H$, Schindzielorz A, et al. Subcellular localization of wild-type and Parkinson's disease-associated mutant a-synuclein in human and transgenic mouse brain. J Neurosci. 2000;20:6365-73.

36. Zhang L, Zhang C, Zhu Y, Cai Q, Chan P, Uéda K, et al. Semi-quantitative analysis of a-synuclein in subcellular pools of rat brain neurons: an immunogold electron microscopic study using a C-terminal specific monoclonal antibody. Brain Res. 2008;1244:40-52.

37. Lee SJ, Jeon $\mathrm{H}$, Kandror KV. Alpha-synuclein is localized in a subpopulation of rat brain synaptic vesicles. Acta Neurobiol Exp (Wars). 2008;68:509-15.

38. Burré J, Sharma M, Tsetsenis T, Buchman V, Etherton MR, Südhof TC. a-Synuclein promotes SNARE-complex assembly in vivo and in vitro. Science. 2010;329:1663-7.

39. Jin H, Kanthasamy A, Ghosh A, Yang Y, Anantharam V, Kanthasamy AG. aSynuclein negatively regulates protein kinase $C \delta$ expression to suppress apoptosis in dopaminergic neurons by reducing p300 histone acetyltransferase activity. J Neurosci. 2011;31:2035-51.

40. Zhu M, Qin ZJ, Hu D, Munishkina LA, Fink AL. a-synuclein can function as an antioxidant preventing oxidation of unsaturated lipid in vesicles. Biochemistry. 2006;45:8135-42.

41. Peng XM, Tehranian R, Dietrich P, Stefanis L, Perez RG. a-Synuclein activation of protein phosphatase $2 \mathrm{~A}$ reduces tyrosine hydroxylase phosphorylation in dopaminergic cells. J Cell Sci. 2005;118:3523-30.

42. Yang W, Wang X, Duan C, Lu L, Yang H. Alpha-synuclein overexpression increases phospho-protein phosphatase $2 \mathrm{~A}$ levels via formation of calmodulin/ Src complex. Neurochem Int. 2013;63:180-94.

43. Polymeropoulos $M H$, Lavedan C, Leroy E, Ide SE, Dehejia A, Dutra A, et al. Mutation in the a-synuclein gene identified in families with Parkinson's disease. Science. 1997:276:2045-7. 
44. Krüger R, Kuhn W, Müller T, Woitalla D, Graeber M, Kösel S, et al. AlaSOPro mutation in the gene encoding a-synuclein in Parkinson's disease. Nat Genet. 1998; 18:106-8.

45. Zarranz JJ, Alegre J, Gómez-Esteban JC, Lezcano E, Ros R, Ampuero I, et al. The new mutation, E46K, of a-synuclein causes parkinson and Lewy body dementia. Ann Neurol. 2004;55:164-73.

46. Appel-Cresswell S, Vilarino-Guell C, Encarnacion M, Sherman H, Yu I, Shah B, et al. Alpha-synuclein p. $\mathrm{H} 50 \mathrm{Q}$, a novel pathogenic mutation for Parkinson's disease. Mov Disord. 2013;28:811-3.

47. Lesage $S$, Anheim M, Letournel F, Bousset L, Honoré A, Rozas N, et al. G51D asynuclein mutation causes a novel Parkinsonian-pyramidal syndrome. Ann Neurol. 2013;73:459-71

48. Proukakis C, Dudzik CG, Brier T, MacKay DS, Cooper JM, Millhauser GL, et al. A novel a-synuclein missense mutation in Parkinson disease. Neurology. 2013;80:1062-4.

49. Singleton A, Farrer M, Johnson J, Singleton A, Hague S, Kachergus J, et al. Synuclein locus triplication causes Parkinson's disease. Science. 2003;302:841.

50. Chartier-Harlin MC, Kachergus J, Roumier C, Mouroux V, Douay X, Lincoln S, et al. a-synuclein locus duplication as a cause of familial Parkinson's disease. Lancet. 2004;364:1167-9.

51. Mellick GD, Maraganore DM, Silburn PA. Australian data and meta-analysis lend support for alpha-synuclein (NACP-Rep1) as a risk factor for Parkinson's disease. Neurosci Lett. 2005;375:112-6.

52. Maraganore DM, De Andrade M, Elbaz A, Farrer MJ, loannidis JP, Krüger R, et al. Collaborative analysis of a-synuclein gene promoter variability and Parkinson disease. J Am Med Assoc. 2006;296:661-70.

53. Chang D, Nalls MA, Hallgrímsdóttir IB, Hunkapiller J, van der Brug M, Cai $F$, et al. A meta-analysis of genome-wide association studies identifies 17 new Parkinson's disease risk loci. Nat Genet. 2017;49:1511-6.

54. Norris EH, Giasson Bl, Lee VM. a-Synuclein: normal function and role in neurodegenerative diseases. Curr Top Dev Biol. 2004;60:17-54.

55. Biancalana $\mathrm{M}$, Koide $\mathrm{S}$. Molecular mechanism of Thioflavin-T binding to amyloid fibrils. Biochim Biophys Acta Proteins Proteom. 2010;1804:1405-12.

56. Fernandez CO, Hoyer W, Zweckstetter M, Jares-Erijman EA, Subramaniam V, Griesinger $C$, et al. NMR of a-synuclein-polyamine complexes elucidates the mechanism and kinetics of induced aggregation. EMBO J. 2004;23:2039-46.

57. Antony T, Hoyer W, Cherny D, Heim G, Jovin TM, Subramaniam V. Cellular polyamines promote the aggregation of a-synuclein. J Biol Chem. 2003;278:3235-40.

58. Wood SJ, Wypych J, Steavenson S, Louis JC, Citron M, Biere AL. a-Synuclein fibrillogenesis is nucleation-dependent Implications for the pathogenesis of Parkinson's disease. J Biol Chem. 1999;274:19509-12.

59. Danzer KM, Haasen D, Karow AR, Moussaud S, Habeck M, Giese A, et al. Different species of a-synuclein oligomers induce calcium influx and seeding. J Neurosci. 2007;27:9220-32.

60. Karpinar DP, Balija MBG, Kügler S, Opazo F, Rezaei-Ghaleh N, Wender N, et al. Pre-fibrillar $\alpha$-synuclein variants with impaired $\beta$-structure increase neurotoxicity in Parkinson's disease models. EMBO J. 2009;28:3256-68.

61. Winner B, Jappelli R, Maji SK, Desplats PA, Boyer L, Aigner S, et al. In vivo demonstration that a-synuclein oligomers are toxic. Proc Natl Acad Sci USA. 2011;108:4194-9.

62. Cremades N, Cohen SI, Deas E, Abramov AY, Chen AY, Orte A, et al. Direct observation of the interconversion of normal and toxic forms of a-synuclein. Cell. 2012;149:1048-59.

63. Choi BK, Choi MG, Kim JY, Yang Y, Lai Y, Kweon DH, et al. Large a-synuclein oligomers inhibit neuronal SNARE-mediated vesicle docking. Proc Natl Acad Sci USA. 2013;110:4087-92.

64. Olanow CW, Perl DP, DeMartino GN, McNaught KSP. Lewy-body formation is an aggresome-related process: a hypothesis. Lancet Neurol. 2004;3:496-503.

65. Tanaka M, Kim YM, Lee G, Junn E, Iwatsubo T, Mouradian MM. Aggresomes formed by a-synuclein and synphilin-1 are cytoprotective. J Biol Chem. 2004:279:4625-31.

66. Hinault M-P, Cuendet AFH, Mattoo RU, Mensi M, Dietler G, Lashuel HA, et al. Stable a-synuclein oligomers strongly inhibit chaperone activity of the Hsp70 system by weak interactions with J-domain co-chaperones. J Biol Chem. 2010;285:38173-82.

67. Lindersson E, Beedholm R, Højrup P, Moos T, Gai W, Hendil KB, et al. Proteasomal inhibition by $a$-synuclein filaments and oligomers. J Biol Chem. 2004:279:12924-34.

68. Colla E, Coune P, Liu Y, Pletnikova O, Troncoso JC, Iwatsubo T, et al. Endoplasmic reticulum stress is important for the manifestations of a-synucleinopathy in vivo. J Neurosci. 2012;32:3306-20.

69. Scott DA, Tabarean I, Tang Y, Cartier A, Masliah E, Roy S. A pathologic cascade leading to synaptic dysfunction in a-synuclein-induced neurodegeneration. J Neurosci. 2010;30:8083-95.
70. Hsu LJ, Sagara Y, Arroyo A, Rockenstein E, Sisk A, Mallory M, et al. a-Synuclein promotes mitochondrial deficit and oxidative stress. Am J Pathol. 2000;157:401-10.

71. Hashimoto M, Kawahara K, Bar-On P, Rockenstein E, Crews L, Masliah E. The role of a-synuclein assembly and metabolism in the pathogenesis of Lewy body disease. J Mol Neurosci. 2004;24:343-52.

72. Alim MA, Ma QL, Takeda K, Aizawa T, Matsubara M, Nakamura M, et al. Demonstration of a role for a-synuclein as a functional microtubule-associated protein. J Alzheimers Dis. 2004;6:435-42.

73. Hüls S, Högen T, Vassallo N, Danzer KM, Hengerer B, Giese A, et al. AMPAreceptor-mediated excitatory synaptic transmission is enhanced by ironinduced a-synuclein oligomers. J Neurochem. 2011;117:868-78.

74. Diógenes MJ, Dias RB, Rombo DM, Miranda HV, Maiolino F, Guerreiro P, et al. Extracellular alpha-synuclein oligomers modulate synaptic transmission and impair LTP via NMDA-receptor activation. J Neurosci. 2012;32:11750-62.

75. Danzer KM, Krebs SK, Wolff M, Birk G, Hengerer B. Seeding induced by asynuclein oligomers provides evidence for spreading of a-synuclein pathology. J Neurochem. 2009;111:192-203.

76. Lee HJ, Suk JE, Patrick C, Bae EJ, Cho JH, Rho S, et al. Direct transfer of asynuclein from neuron to astroglia causes inflammatory responses in synucleinopathies. J Biol Chem. 2010;285:9262-72.

77. Brettschneider J, Del Tredici K, Lee VM, Trojanowski JQ. Spreading of pathology in neurodegenerative diseases: a focus on human studies. Nat Rev Neurosci. 2015;16:109-20.

78. Eberling JL, Dave KD, Frasier MA. a-Synuclein imaging: a critical need for Parkinson's disease research. J Parkinsons Dis. 2013;3:565-7.

79. Schapira AH, Olanow CW, Greenamyre JT, Bezard E. Slowing of neurodegeneration in Parkinson's disease and Huntington's disease: future therapeutic perspectives. Lancet. 2014;384:545-55.

80. Cui M. Past and recent progress of molecular imaging probes for $\beta$-amyloid plaques in the brain. Curr Med Chem. 2014:21:82-112.

81. Ye L, Velasco A, Fraser G, Beach TG, Sue L, Osredkar T, et al. In vitro high affinity a-synuclein binding sites for the amyloid imaging agent PIB are not matched by binding to Lewy bodies in postmortem human brain. J Neurochem. 2008;105:1428-37.

82. Fodero-Tavoletti MT, Smith DP, McLean CA, Adlard PA, Barnham KJ, Foster LE, et al. In vitro characterization of Pittsburgh compound-B binding to Lewy bodies. J Neurosci. 2007;27:10365-71.

83. Fodero-Tavoletti MT, Mulligan RS, Okamura N, Furumoto S, Rowe CC, Kudo Y, et al. In vitro characterisation of BF227 binding to alpha-synuclein/Lewy bodies. Eur J Pharmacol. 2009;617:54-8.

84. Levigoureux $E$, Lancelot $S$, Bouillot $C$, Chauveau F, Verdurand $M$, Verchere J, et al. Binding of the PET radiotracer $\left[{ }^{18} \mathrm{~F}\right] \mathrm{BF} 227$ does not reflect the presence of alpha-synuclein aggregates in transgenic mice. Curr Alzheimer Res. 2014;11:955-60.

85. Yu L, Cui J, Padakanti PK, Engel L, Bagchi DP, Kotzbauer PT, et al. Synthesis and in vitro evaluation of alpha-synuclein ligands. Bioorg Med Chem. 2012;20:4625-34.

86. Bagchi DP, Yu L, Perlmutter JS, Xu J, Mach RH, Tu Z, et al. Binding of the radioligand SIL23 to alpha-synuclein fibrils in Parkinson disease brain tissue establishes feasibility and screening approaches for developing a Parkinson disease imaging agent. PLoS One. 2013;8:e55031.

87. Zhang X, Jin H, Padakanti PK, Li J, Yang H, Fan J, et al. Radiosynthesis and in Vivo Evaluation of Two PET Radioligands for Imaging alpha-Synuclein. Appl Sci. 2014;4:66-78

88. Chu W, Zhou D, Gaba V, Liu J, Li S, Peng X, et al. Design, synthesis, and characterization of 3-(benzylidene)indolin-2-one derivatives as ligands for alphasynuclein fibrils. J Med Chem. 2015:58:6002-17.

89. Ono $M$, Doi $Y$, Watanabe $H$, Ihara $M$, Ozaki $A$, Saji $H$. Structure activity relationships of radioiodinated diphenyl derivatives. RSC Adv. 2016;6:44305-12.

90. Watanabe $H$, Ariyoshi T, Ozaki A, Ihara M, Ono M, Saji H. Synthesis and biological evaluation of novel radioiodinated benzimidazole derivatives for imaging alphasynuclein aggregates. Bioorg Med Chem. 2017;25:6398-403.

91. Mason NS, Mathis CA, Klunk WE. Positron emission tomography radioligands for in vivo imaging of $A \beta$ plaques. J Label Comp Radiopharm. 2013;56:89-95.

92. Okamura N, Harada R, Furumoto S, Arai H, Yanai K, Kudo Y. Tau PET imaging in Alzheimer's disease. Curr Neurol Neurosci Rep. 2014;14:500.

93. Kotzbauer PT, Tu Z, Mach RH. Current status of the development of PET radiotracers for imaging alpha synuclein aggregates in Lewy bodies and Lewy neurites. Clin Transl Imaging. 2016;5:3-14.

94. Xu M, Ren W, Tang X, Hu Y, Zhang H. Advances in development of fluorescent probes for detecting amyloid- $\beta$ aggregates. Acta Pharmacol Sin. 2016;37:719-30.

95. Celej MS, Jares-Erijman EA, Jovin TM. Fluorescent $\mathrm{N}$-arylaminonaphthalene sulfonate probes for amyloid aggregation of alpha-synuclein. Biophys J. 2008;94: 4867-79. 
96. Volkova KD, Kovalska VB, Balanda AO, Losytskyy MY, Golub AG, Vermeij RJ, et al. Specific fluorescent detection of fibrillar alpha-synuclein using mono- and trimethine cyanine dyes. Bioorg Med Chem. 2008;16:1452-9.

97. Lee JH, Lee IH, Choe YJ, Kang S, Kim HY, Gai WP, et al. Real-time analysis of amyloid fibril formation of alpha-synuclein using a fibrillation-state-specific fluorescent probe of JC-1. Biochem J. 2009;418:311-23.

98. Makwana PK, Jethva PN, Roy I. Coumarin 6 and 1,6-diphenyl-1,3,5-hexatriene (DPH) as fluorescent probes to monitor protein aggregation. Analyst. 2011;136:2161-7.

99. Kovalska VB, Losytskyy MY, Tolmachev Ol, Slominskii YL, Segers-Nolten GM, Subramaniam $V$, et al. Tri- and pentamethine cyanine dyes for fluorescent detection of alpha-synuclein oligomeric aggregates. J Fluoresc. 2012;22:1441-8.

100. Leung CW, Leung CW, Guo F, Hong Y, Zhao E, Kwok RT, et al. Detection of oligomers and fibrils of $a$-synuclein by AlEgen with strong fluorescence. Chem Commun. 2015;51:1866-9.

101. Deeg AA, Reiner AM, Schmidt F, Schueder F, Ryazanov S, Ruf VC, et al. Anle138b and related compounds are aggregation specific fluorescence markers and reveal high affinity binding to alpha-synuclein aggregates. Biochim Biophys Acta. 2015;1850:1884-90.

102. Watanabe $H$, Ono $M$, Ariyoshi $T$, Katayanagi $R$, Saji $H$. Novel benzothiazole derivatives as fluorescent probes for detection of beta-amyloid and alphasynuclein aggregates. ACS Chem Neurosci. 2017;8:1656-62.

103. Li J, Zhu M, Rajamani S, Uversky VN, Fink AL. Rifampicin inhibits alpha-synuclein fibrillation and disaggregates fibrils. Chem Biol. 2004;11:1513-21.

104. Xu J, Wei C, Xu C, Bennett MC, Zhang G, Li F, et al. Rifampicin protects PC12 cells against $\mathrm{MPP}^{+}$-induced apoptosis and inhibits the expression of an a-synuclein multimer. Brain Res. 2007;1139:220-5.

105. Ono K, Yamada M. Antioxidant compounds have potent anti-fibrillogenic and fibril-destabilizing effects for alpha-synuclein fibrils in vitro. J Neurochem. 2006;97:105-15.

106. Li HT, Lin DH, Luo XY, Zhang F, Ji LN, Du HN, et al. Inhibition of alpha-synuclein fibrillization by dopamine analogs via reaction with the amino groups of alphasynuclein. Implication for dopaminergic neurodegeneration. FEBS J. 2005;272:3661-72.

107. Herrera FE, Chesi A, Paleologou KE, Schmid A, Munoz A, Vendruscolo M, et al. Inhibition of a-synuclein fibrillization by dopamine is mediated by interactions with five C-terminal residues and with E83 in the NAC region. PLoS One. 2008;3: e3394.

108. Latawiec D, Herrera F, Bek A, Losasso V, Cndotti M, Benetti F, et al. Modulation of alpha-synuclein aggregation by dopamine analogs. PLoS One. 2010;16:e9234.

109. Masuda M, Suzuki N, Taniguchi S, Oikawa T, Nonaka T, Iwatsubo T, et al. Small molecule inhibitors of alpha-synuclein filament assembly. Biochemistry. 2006;45:6085-94.

110. Lendel C, Bertoncini CW, Cremades N, Waudby CA, Vendruscolo M, Dobson CM et al. On the mechanism of nonspecific inhibitors of protein aggregation: dissecting the interactions of alpha-synuclein with Congo red and lacmoid. Biochemistry. 2009;48:8322-34.

111. Lamberto GR, Binolfi A, Orcellet ML, Bertoncini CW, Zweckstetter M, Griesinger $C$, et al. Structural and mechanistic basis behind the inhibitory interaction of PcTS on alpha-synuclein amyloid fibril formation. Proc Natl Acad Sci USA. 2009;106:21057-62.

112. Valiente-Gabioud AA, Miotto MC, Chesta ME, Lombardo V, Binolfi A, Fernández $\mathrm{CO}$. Phthalocyanines as molecular scaffolds to block disease-associated protein aggregation. Acc Chem Res. 2016;49:801-8.

113. Ahsan N, Siddique IA, Gupta S, Surolia A. A routinely used protein staining dye acts as an inhibitor of wild type and mutant alpha-synuclein aggregation and modulator of neurotoxicity. Eur J Med Chem. 2018;143:1174-84.

114. Howlett D, Cutler P, Heales S, Camilleri P. Hemin and related porphyrins inhibit $\beta$-amyloid aggregation. FEBS Lett. 1997;417:249-51.

115. Liu Y, Carver JA, Ho LH, Elias AK, Musgrave IF, Pukala TL. Hemin as a generic and potent protein misfolding inhibitor. Biochem Biophys Res Commun. 2014:454:295-300.

116. Liu Y, Graetz M, Ho L, Pukala TL. Ion mobility-mass spectrometry-based screening for inhibition of alpha-synuclein aggregation. Eur J Mass Spectrom. 2015;21:255-64.

117. Young LM, Saunders JC, Mahood RA, Revill CH, Foster RJ, Tu LH, et al. Screening and classifying small-molecule inhibitors of amyloid formation using ion mobility spectrometry-mass spectrometry. Nat Chem. 2015;7:73-81.

118. Pandey N, Strider J, Nolan WC, Yan SX, Galvin JE. Curcumin inhibits aggregation of alpha-synuclein. Acta Neuropathol. 2008;115:479-89.

119. Singh PK, Kotia V, Ghosh D, Mohite GM, Kumar A, Maji SK. Curcumin modulates alpha-synuclein aggregation and toxicity. ACS Chem Neurosci. 2013;4:393-407.

120. Ahsan N, Mishra S, Jain MK, Surolia A, Gupta S. Curcumin pyrazole and its derivative ( $\mathrm{N}$-(3-nitrophenylpyrazole) curcumin inhibit aggregation, disrupt fibrils and modulate toxicity of wild type and mutant alpha-synuclein. Sci Rep. 2015;5:9862.

121. Jha NN, Ghosh D, Das S, Anoop A, Jacob RS, Singh PK, et al. Effect of curcumin analogs on a-synuclein aggregation and cytotoxicity. Sci Rep. 2016;6:28511.

122. Ehrnhoefer DE, Bieschke J, Boeddrich A, Herbst M, Masino L, Lurz R, et al. EGCG redirects amyloidogenic polypeptides into unstructured, off-pathway oligomers. Nat Struct Mol Biol. 2008;15:558-66.

123. Konijnenberg A, Ranica S, Narkiewicz J, Legname G, Grandori R, Sobott F, et al. Opposite structural effects of epigallocatechin-3-gallate and dopamine binding to alpha-synuclein. Anal Chem. 2016;88:8468-75.

124. Bieschke J, Russ J, Friedrich RP, Ehrnhoefer DE, Wobst $\mathrm{H}$, Neugebauer K, et al. EGCG remodels mature alpha-synuclein and amyloid-beta fibrils and reduces cellular toxicity. Proc Natl Acad Sci USA. 2010;107:7710-5.

125. Lorenzen N, Nielsen SB, Yoshimura Y, Vad BS, Andersen CB, Betzer C, et al. How epigallocatechin gallate can inhibit alpha-synuclein oligomer toxicity in vitro. $J$ Biol Chem. 2014;289:21299-310.

126. Chen M, Wang T, Yue F, Li X, Wang $P$, Li Y, et al. Tea polyphenols alleviate motor impairments, dopaminergic neuronal injury, and cerebral a-synuclein aggregation in MPTP-intoxicated parkinsonian monkeys. Neuroscience. 2015;286:383-92.

127. Grelle G, Otto A, Lorenz M, Frank RF, Wanker EE, Bieschke J. Black tea theaflavins inhibit formation of toxic amyloid-beta and alpha-synuclein fibrils. Biochemistry. 2011;50:10624-36.

128. Rivière $C$, Papastamoulis $\mathrm{Y}$, Fortin PY, Delchier N, Andriamanarivo S, WaffoTeguo $P$, et al. New stilbene dimers against amyloid fibril formation. Bioorg Med Chem Lett. 2010;20:3441-3.

129. Temsamani H, Krisa S, Decossas-Mendoza M, Lambert O, Merillon JM, Richard T. Piceatannol and other wine stilbenes: a pool of inhibitors against alphasynuclein aggregation and cytotoxicity. Nutrients. 2016;8:367.

130. Caruana M, Hogen T, Levin J, Hillmer A, Giese A, Vassallo N. Inhibition and disaggregation of alpha-synuclein oligomers by natural polyphenolic compounds. FEBS Lett. 2011;585:1113-20.

131. Hung KC, Huang HJ, Wang YT, Lin AM. Baicalein attenuates alpha-synuclein aggregation, inflammasome activation and autophagy in the $\mathrm{MPP}^{+}$. treated nigrostriatal dopaminergic system in vivo. J Ethnopharmacol. 2016;194:522-9.

132. Hu Q, Uversky VN, Huang $M$, Kang $H, X u F$, Liu $X$, et al. Baicalein inhibits alphasynuclein oligomer formation and prevents progression of alpha-synuclein accumulation in a rotenone mouse model of Parkinson's disease. Biochim Biophys Acta. 2016;1862:1883-90.

133. Hornedo-Ortega R, Alvarez-Fernandez MA, Cerezo AB, Richard T, Troncoso AM, Garcia-Parrilla MA. Protocatechuic acid: inhibition of fibril formation, destabilization of preformed fibrils of amyloid-beta and alpha-synuclein, and neuroprotection. J Agric Food Chem. 2016;64:7722-32.

134. Palazzi L, Bruzzone E, Bisello G, Leri M, Stefani M, Bucciantini M, et al. Oleuropein aglycone stabilizes the monomeric alpha-synuclein and favours the growth of non-toxic aggregates. Sci Rep. 2018;8:8337.

135. Hornedo-Ortega R, Cerezo AB, Troncoso AM, Garcia-Parrilla MC. Protective effects of hydroxytyrosol against alpha-synuclein toxicity on PC12cells and fibril formation. Food Chem Toxicol. 2018;120:41-9.

136. Olthof MR, Hollman PC, Vree TB, Katan MB. Bioavailabilities of quercetin-3 glucoside and quercetin-4'-glucoside do not differ in humans. J Nutr. 2000;130:1200-3.

137. Gadad BS, Subramanya PK, Pullabhatla S, Shantharam IS, Rao KS. Curcuminglucoside, a novel synthetic derivative of curcumin, inhibits a-synuclein oligomer formation relevance to Parkinson's disease. Curr Pharm Des. 2012;18:76-84.

138. Ardah MT, Paleologou KE, Lv G, Menon SA, Abul Khair SB, Lu JH, et al. Ginsenoside $\mathrm{Rb} 1$ inhibits fibrillation and toxicity of alpha-synuclein and disaggregates preformed fibrils. Neurobiol Dis. 2015;74:89-101.

139. Liao M, Zhao Y, Huang L, Cheng B, Huang K. Isoliquiritigenin and liquiritin from Glycyrrhiza uralensis inhibit a-synuclein amyloid formation. RSC Adv. 2016;6:86640.

140. da Silva FL, Coelho Cerqueira E, de Freitas MS, Goncalves DL, Costa LT, Follmer C. Vitamins $\mathrm{K}$ interact with $\mathrm{N}$-terminus alpha-synuclein and modulate the protein fibrillization in vitro. Exploring the interaction between quinones and alphasynuclein. Neurochem Int. 2013;62:103-12.

141. Ji K, Zhao Y, Yu T, Wang Z, Gong H, Yang X, et al. Inhibition effects of tanshinone on the aggregation of alpha-synuclein. Food Funct. 2016;7:409-16.

142. Sashidhara KV, Modukuri RK, Jadiya P, Rao KB, Sharma T, Haque R, et al. Discovery of 3-Arylcoumarin-tetracyclic tacrine hybrids as multifunctional agents against Parkinson's disease. ACS Med Chem Lett. 2014;5:1099-103.

143. Galvagnion C, Buell AK, Meisl G, Michaels TC, Vendruscolo M, Knowles TP, et al. Lipid vesicles trigger a-synuclein aggregation by stimulating primary nucleation. Nat Chem Biol. 2015;11:229-34. 
144. Yeung T, Gilbert GE, Shi J, Silvius J, Kapus A, Grinstein S. Membrane phosphatidylserine regulates surface charge and protein localization. Science. 2008;319:210-3.

145. Perni M, Galvagnion C, Maltsev A, Meisl G, Muller MB, Challa PK, et al. A natural product inhibits the initiation of alpha-synuclein aggregation and suppresses its toxicity. Proc Natl Acad Sci USA. 2017;114:E1009-E17.

146. Perni M, Flagmeier P, Limbocker R, Cascella R, Aprile FA, Galvagnion C, et al. Multistep inhibition of alpha-synuclein aggregation and toxicity in vitro and in vivo by trodusquemine. ACS Chem Biol. 2018;13:2308-19.

147. Pineda A, Burré J. Modulating membrane binding of a-synuclein as a therapeutic strategy. Proc Natl Acad Sci USA. 2017;114:1223-5.

148. Wrasidlo W, Tsigelny IF, Price DL, Dutta G, Rockenstein E, Schwarz TC. et al. A de novo compound targeting alpha-synuclein improves deficits in models of Parkinson's disease. Brain. 2016;139:3217-36.

149. Price DL, Koike MA, Khan A, Wrasidlo W, Rockenstein E, Masliah E, et al. The small molecule alpha-synuclein misfolding inhibitor, NPT200-11, produces multiple benefits in an animal model of Parkinson's disease. Sci Rep. 2018; 8:16165.

150. Qin Z, Hu D, Han S, Reaney SH, Di Monte DA, Fink AL. Effect of 4-hydroxy-2-nonenal modification on alpha-synuclein aggregation. J Biol Chem. 2007;282:5862-70.

151. Ibrahim T, McLaurin J. alpha-Synuclein aggregation, seeding and inhibition by scyllo-inositol. Biochem Biophys Res Commun. 2016:469:529-34.

152. Cha SH, Heo SJ, Jeon YJ, Park SM. Dieckol, an edible seaweed polyphenol, retards rotenone-induced neurotoxicity and a-synuclein aggregation in human dopaminergic neuronal cells. RSC Adv. 2016;6:110040.

153. Ono K, Mochizuki $\mathrm{H}$, Ikeda T, Nihira T, Takasaki J, Teplow DB, et al. Effect of melatonin on a-synuclein self-assembly and cytotoxicity. Neurobiol Aging. 2012; 33:2172-85.

154. Braga CA, Follmer C, Palhano FL, Khattar E, Freitas MS, Romao L, et al. The antiParkinsonian drug selegiline delays the nucleation phase of alpha-synuclein aggregation leading to the formation of nontoxic species. J Mol Biol. 2011;405: 254-73.

155. Pujols J, Pena-Diaz S, Lazaro DF, Peccati F, Pinheiro F, Gonzalez D, et al. Small molecule inhibits alpha-synuclein aggregation, disrupts amyloid fibrils, and prevents degeneration of dopaminergic neurons. Proc Natl Acad Sci USA. 2018;115:10481-6.
156. Pujols J, Pena-Diaz S, Conde-Gimenez M, Pinheiro F, Navarro S, Sancho J, et al. High-throughput screening methodology to identify alpha-synuclein aggregation inhibitors. Int J Mol Sci. 2017;18:478.

157. Prabhudesai S, Sinha S, Attar A, Kotagiri A, Fitzmaurice AG, Lakshmanan R, et al. A novel "molecular tweezer" inhibitor of alpha-synuclein neurotoxicity in vitro and in vivo. Neurotherapeutics. 2012;9:464-76.

158. Richter F, Subramaniam SR, Magen I, Lee P, Hayes J, Attar A, et al. A molecular tweezer ameliorates motor deficits in mice overexpressing alpha-synuclein. Neurotherapeutics 2017;14:1107-19.

159. Wagner J, Ryazanov S, Leonov A, Levin J, Shi S, Schmidt F, et al. Anle138b: a novel oligomer modulator for disease-modifying therapy of neurodegenerative diseases such as prion and Parkinson's disease. Acta Neuropathol. 2013;125:795-813.

160. Tatenhorst L, Eckermann K, Dambeck V, Fonseca-Ornelas L, Walle H, Lopes da Fonseca $\mathrm{T}$, et al. Fasudil attenuates aggregation of alpha-synuclein in models of Parkinson's disease. Acta Neuropathol Commun. 2016:4:39.

161. Hamrang Z, Rattray NJ, Pluen A. Proteins behaving badly: emerging technologies in profiling biopharmaceutical aggregation. Trends Biotechnol. 2013;31:448-58.

162. Jameson LP, Smith NW, Dzyuba SV. Dye-binding assays for evaluation of the effects of small molecule inhibitors on amyloid $(A \beta)$ self-assembly. ACS Chem Neurosci. 2012;3:807-19.

163. Cheng $X$, van Breemen RB. Mass spectrometry-based screening for inhibitors of $\beta$-amyloid protein aggregation. Anal Chem. 2005;77:7012-5.

164. Xie Y, Zhang J, Yin S, Loo JA. Top-down ESI-ECD-FT-ICR mass spectrometry localizes noncovalent protein-ligand binding sites. J Am Chem Soc. 2006;128:14432-3.

165. Acharya S, Safaie BM, Wongkongkathep P, Ivanova MI, Attar A, Klärner FG, et al. Molecular basis for preventing a-synuclein aggregation by a molecular tweezer. J Biol Chem. 2014;289:10727-37.

166. Xu M, Loa-Kum-Cheng W, Zhang H, Quinn RJ, Mellick GD. Identification of a new a-synuclein aggregation inhibitor via mass spectrometry based screening. ACS Chem Neurosci. 2019;10:2683-91.

167. Ai X, Ho CJ, Aw J, Attia AB, Mu J, Wang Y, et al. In vivo covalent cross-linking of photon-converted rare-earth nanostructures for tumour localization and theranostics. Nat Commun. 2016;7:10432.

168. Zhang X, Tian Y, Yuan P, Li Y, Yaseen MA, Grutzendler J, et al. A bifunctional curcumin analogue for two-photon imaging and inhibiting crosslinking of amyloid beta in Alzheimer's disease. Chem Commun. 2014;50:11550-3. 